
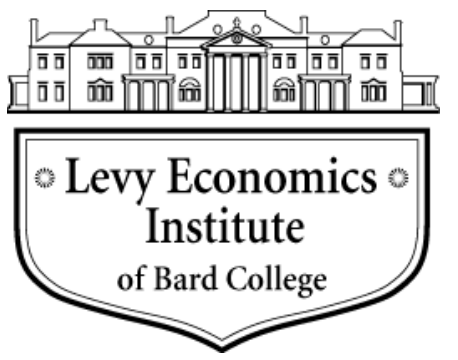

Working Paper No. 956

\title{
An Empirical Analysis of Long-Term Brazilian Interest Rates
}

\author{
by \\ Tanweer Akram \\ General Motors \\ and \\ Syed Al-Helal Uddin \\ College of Saint Benedict and Saint John's University
}

May 2020

\begin{abstract}
* The authors thank the participants in various seminars for their invaluable comments and suggestions. They also thank Ms. Elizabeth Dunn and Ms. Mary Rafferty for their editorial assistance. The authors' institutional affiliations are provided solely for identification purposes. Views expressed are solely those of the authors. The standard disclaimer holds. This research did not receive any specific grant from funding agencies in the public, commercial, or not-for-profit sectors. The dataset used in the empirical part of this paper is available upon request to bona fide researchers for the replication and verification of the results.

The Levy Economics Institute Working Paper Collection presents research in progress by Levy Institute scholars and conference participants. The purpose of the series is to disseminate ideas to and elicit comments from academics and professionals.
\end{abstract}

Levy Economics Institute of Bard College, founded in 1986, is a nonprofit, nonpartisan, independently funded research organization devoted to public service. Through scholarship and economic research it generates viable, effective public policy responses to important economic problems that profoundly affect the quality of life in the United States and abroad.

\author{
Levy Economics Institute \\ P.O. Box 5000 \\ Annandale-on-Hudson, NY 12504-5000 \\ http://www.levyinstitute.org
}

Copyright (C) Levy Economics Institute 2020 All rights reserved

ISSN 1547-366X 


\begin{abstract}
This paper empirically models the dynamics of Brazilian government bond (BGB) yields based on monthly macroeconomic data in the context of the evolution of Brazil's key macroeconomic variables. The results show that the current short-term interest rate has a decisive influence on BGBs' long-term interest rates after controlling for various key macroeconomic variables, such as inflation and industrial production or economic activity. These findings support John Maynard Keynes's claim that the central bank's actions influence the long-term interest rate on government bonds mainly through the short-term interest rate. These findings have important policy implications for Brazil. This paper relates the findings of the estimated models to ongoing debates in fiscal and monetary policies.
\end{abstract}

KEYWORDS: Brazilian Government Bonds; Long-Term Interest Rate; Bond Yields; Monetary Policy; Short-Term Interest Rate; Banco Central do Brasil (BCB)

JEL CLASSIFICATION: E43; E50; E58; E60; G10; G12 


\section{INTRODUCTION}

John Maynard Keynes (1930, 352-64) argued that a country's central bank has a decisive influence on the long-term interest rate on government bonds mainly through its monetary policy. He believed that the central bank's policy rate sets the short-term interest rate, which in turn has a crucial effect on the long-term interest rate. This paper examines whether Keynes's argument that the short-term interest rate is the key driver of the long-term interest rate holds for Brazil, after controlling for several key macroeconomic variables, such as the rate of inflation, and the pace of economic activity or industrial production.

This paper contributes to the literature on the dynamics of government bond yields by examining Brazilian government bond (BGB) yields from a Keynesian approach. Understanding the empirics of BGB yields is an important question, not just for macroeconomists but also for policymakers and domestic and international investors in Brazilian financial markets. The empirical findings pertaining to the dynamics of BGB yields can be useful for policy purposes and policy modeling, and analyzing the effects of fiscal policy, monetary policy, and the monetary transmission mechanism on financial markets. It is also germane for portfolio managers and investors interested in asset allocation in emerging markets and the public sector managers of government debt and Treasury operations. There have been a few empirical analyses of Latin American government bond yields from a Keynesian approach. Hence, this paper fills a relevant gap in the literature. It can provide some valuable insights about the relevance of the Keynesian approach to government bond yields and financial markets to both macro theorists and policymakers.

The paper is structured as follows. Section II briefly describes Keynes's view on interest rates. It also provides an overview of the Keynesian models used in this paper. It relates this paper to ongoing debates in the literature on government bond yields. Section III gives a short summary of the evolution of BGB yields with reference to the relevant macroeconomic developments in Brazil. Section IV explains the data and relates the variables to the behavioral equations of the models. It also presents the econometric methodology applied in the paper. It reports and interprets the empirical findings from the models estimated here. Section V concludes with a 
discussion of the implications of the empirical findings for both macroeconomic theory and economic policies in Brazil.

\section{THE KEYNESIAN MODEL OF LONG-TERM INTEREST RATES AND THE RELATED LITERATURE}

Substantial literature exists on empirical models of government bond yields. Simoski $(2019$, 821) provides a succinct overview of the debates in the empirical literature on government bond yields, including two contending viewpoints.

The dominant view is that a higher government debt or deficit ratio leads to higher government bond yields. This viewpoint is represented by the neoclassical perspective, such as Ardagna, Caselli, and Lane (2007), Baldacci and Kumar (2010), Cebula (2014), Das et al. (2010), Gruber and Kamin (2012), Horioka, Nomoto, and Terada-Hagiwara (2014), Hoshi and Ito (2013, 2014), Martinez, Terecnmoa, and Teruelb (2013), Min et al. (2003), Poghosyan (2014), Reinhart and Rogoff (2009), and Tkačeves and Vilerts (2016, 2019). This view is based on the loanable funds theory. According to this theory, the interest rate is simply the price of loanable funds. It holds that the supply of loanable funds (or saving) is discouraged (encouraged) by low (high) interest rates. Increased government net borrowing leads to higher demand for funds. Given a supply schedule, higher demand for funds raises the equilibrium interest rate.

In contrast to the dominant view, a minority view maintains that the central bank's action, particularly its policy rate, is the key driver of government bond yields. This viewpoint originates from Keynes (1930, [1936] 2007), who was inspired by Riefler's (1930) empirical analysis of the long-term interest rate in the United States. Keynes ([1936] 2007, 167) firmly rejects the view that the interest rate is "a return to saving or waiting" or "the "price' which brings into equilibrium the demand for resources to investment with the readiness to abstain from present consumption." Instead, he maintains that the interest rate is "the reward for parting with liquidity for a specified period," which "equilibrates the desire to hold wealth in the form of cash with the available quantity of cash." 
The Keynesian approach to interest rates is represented in Akram and Das (2014, 2015, 2017, 2019a, 2019b, 2020), Akram and Li (2016, 2017, 2018, 2019, 2020), Fullwiler (2016), Kregel (2011), Lavoie (2014), Levrero and Deleidi (2019), Simoski (2019), and Wray ([1998] 2003, 2012). The Keynesian approach to government bond market dynamics draws on a wide range of theoretical arguments in the literature, such as Bindseil (2004), Davidson (2015), Goodheart (1998), Knapp ([1926] 1973), Lerner (1943, 1947), Sims (2013), and Tcherneva (2011). It is also draws on various empirical analysis and policy discussions, such as Bolukbas (2018), Kurihara (2015), Malliaropulos and Migiakis (2018), Mattos et al. (2019), Patra et al. (2016), and Sau (2018).

This paper contributes to the literature in several propitious ways. First, it econometrically models government bond yields in Brazil, a major emerging market country. It is useful to examine whether Keynes's conjecture holds for an emerging market country, such as Brazil. Second, it extends the research program of the Keynesian approach on government bond yields to the case of Brazil. Third, it relates the developments in the BGB market to macroeconomic fundamentals and recent economic developments in Brazil. Fourth, it discerns the implications of the findings from the empirical modeling of the dynamics of the Brazilian government bond market for fiscal and monetary policies, not only in Brazil but also for emerging market countries that issue government debt in their own currencies and exercise monetary sovereignty. This paper contributes to the ongoing debates on the empirical analysis of government bond yield dynamics in the growing literature on government bond markets in emerging market countries. ${ }^{3}$

\footnotetext{
${ }^{3}$ See Akram and Das (2015, 2019a), Jaramillo and Weber (2013), Martinez, Tercenoa, and Teruelb (2013), Malliaroplus and Migiakis (2018), Patra et al. (2016), and Turner (2002) for examples of the current debates in the literature on government bond yields in emerging markets.
} 


\section{THE EVOLUTION OF BRAZILIAN GOVERNMENT BOND YIELDS AND MACROECOMIC DEVELOPMENTS IN BRAZIL}

The figures below show the evolution of the relevant macroeconomic variables related to government bond yields in Brazil from 2007 to 2018. The shaded areas in light grey in the figures are the periods of recession. Since 2014, the Brazilian economy has slowed down noticeably. In recent years, Brazil has suffered from political uncertainty, weakness in growth, elevated inflation, a currency depreciation, and volatility in the currency exchange rate (Cardim de Carvalho 2016a, 2016b, 2017), even though Brazil is a country with tremendous potential (Kregel 2009).

Figure 1 shows the evolution of key interest rates in Brazil. Long-term interest rates on government bonds rose sharply from around 11 percent in early 2007 to almost 18 percent by mid-2008, but fell noticeably just before the onset of the recession in 2009 as the Banco Central do Brasil (BCB), the country’s central bank, cut its policy rate. Long-term interest rates were fairly steady from 2009 to mid-2011, even as the BCB started hiking the policy rate in mid-2010. Long-term interest rates began to decline from mid-2011 to early 2013 as the BCB gradually reduced its policy rate. As the BCB renewed tighter monetary policy, long-term interest rates rose from mid-2013 to mid-2015. Long-term interest rates started declining in anticipation of a reduction in the BCB's policy rate in late 2015. This decline generally continued as the BCB lowered its policy rate from late 2016 to early 2018. However, long-term interest rates initially rose in mid-2018 even though the BCB held the policy rate steady. Eventually by late 2018 longterm interest rates began to decline. 
Figure 1: The Evolution of Key Interest Rates in Brazil, 2007-18

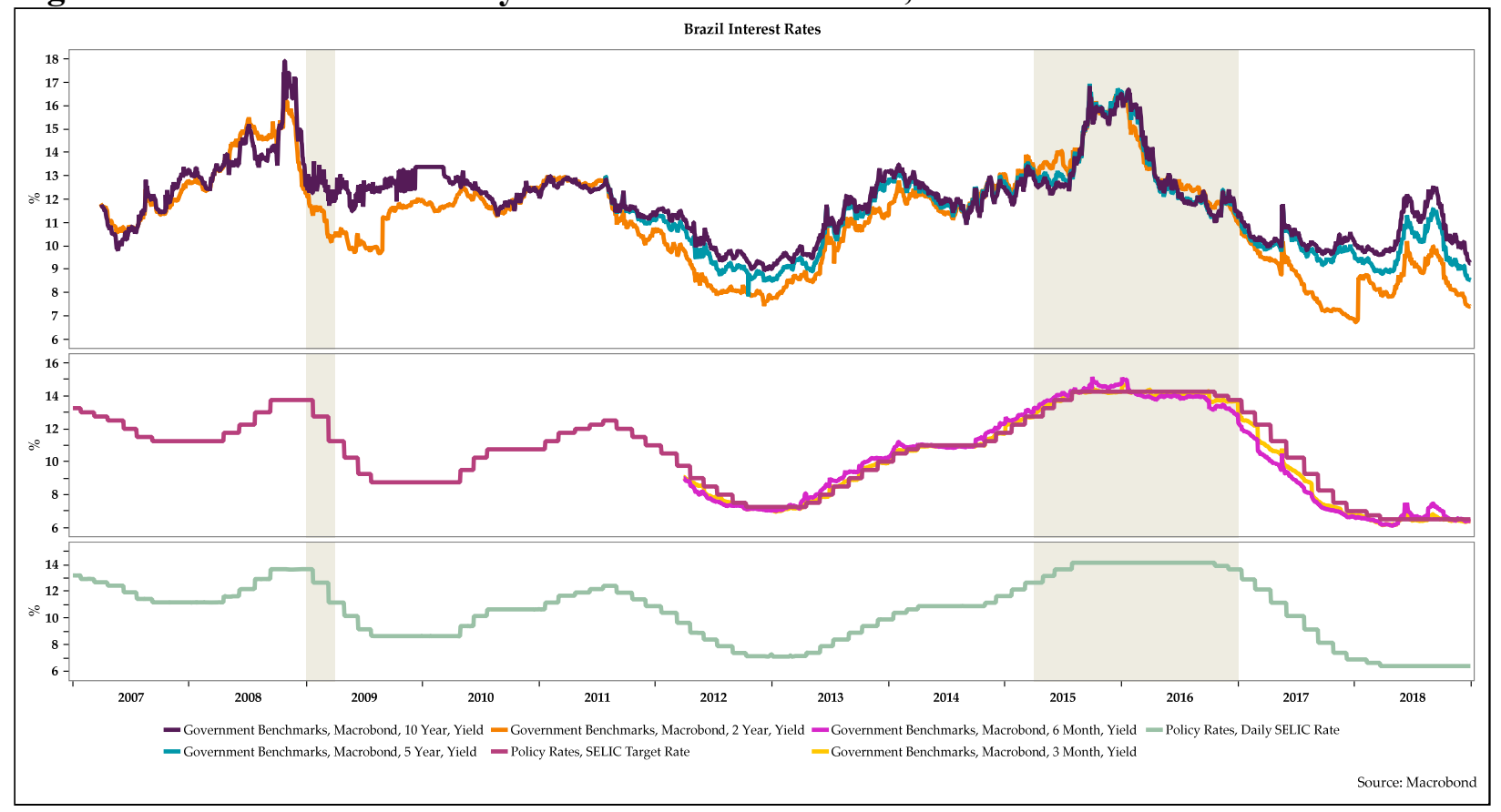

Figure 2 displays the evolution of targeted and effective policy rates and short-term swap rates. It reveals that short-term swap rates are tightly connected with the BCB's policy rate.

Figure 2: The Evolution of Policy Rates and Swap Rates in Brazil, 2007-18

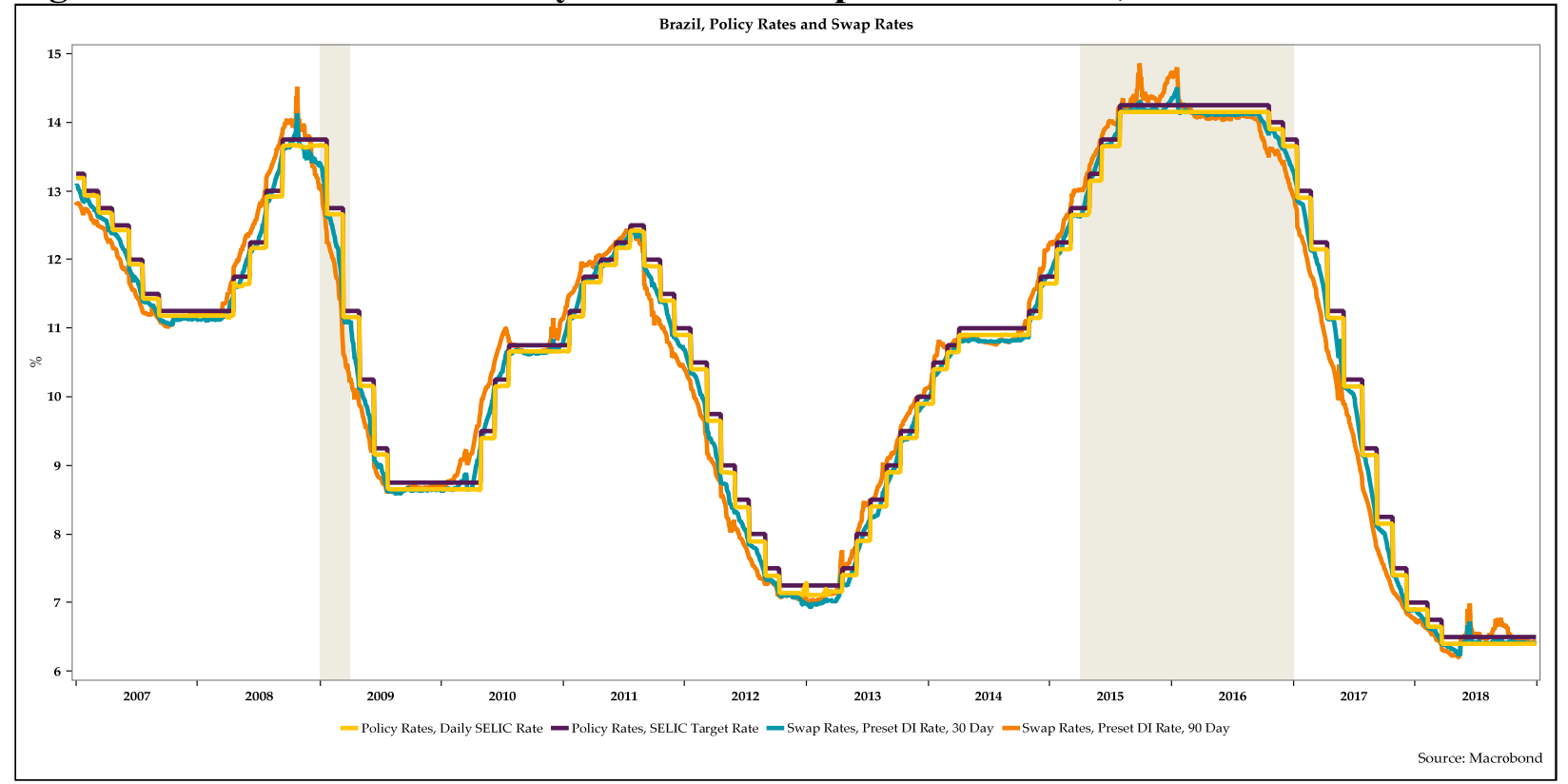


Figure 3 shows the evolution of economic activity as measured by year-over-year changes in monthly gross domestic product (GDP) and monthly industrial production.

Figure 3: The Evolution of Economic Activity and Industrial Production in Brazil, 2007-18

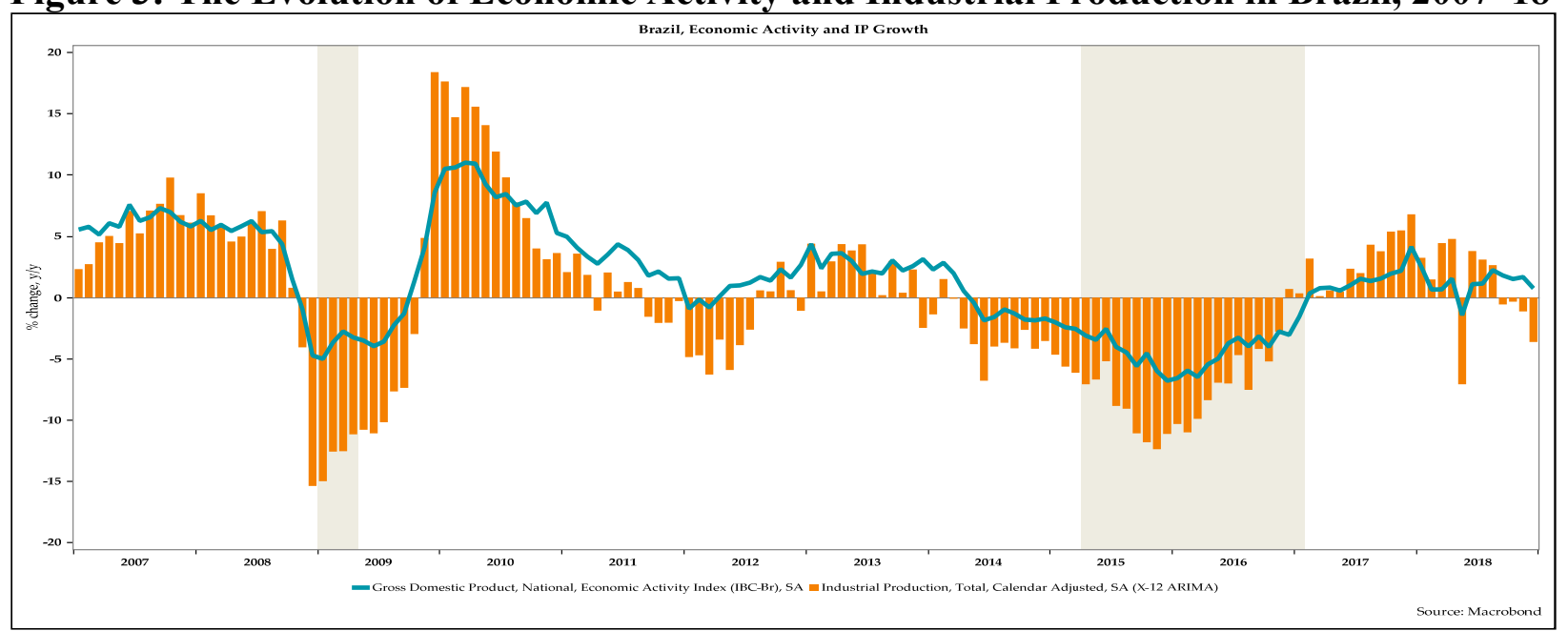

The scatterplot in figure 4 affirms that the year-over-year changes in monthly GDP and industrial production are strongly correlated.

Figure 4: Scatterplot of GDP Growth and Industrial Production Growth in Brazil, 2007-18

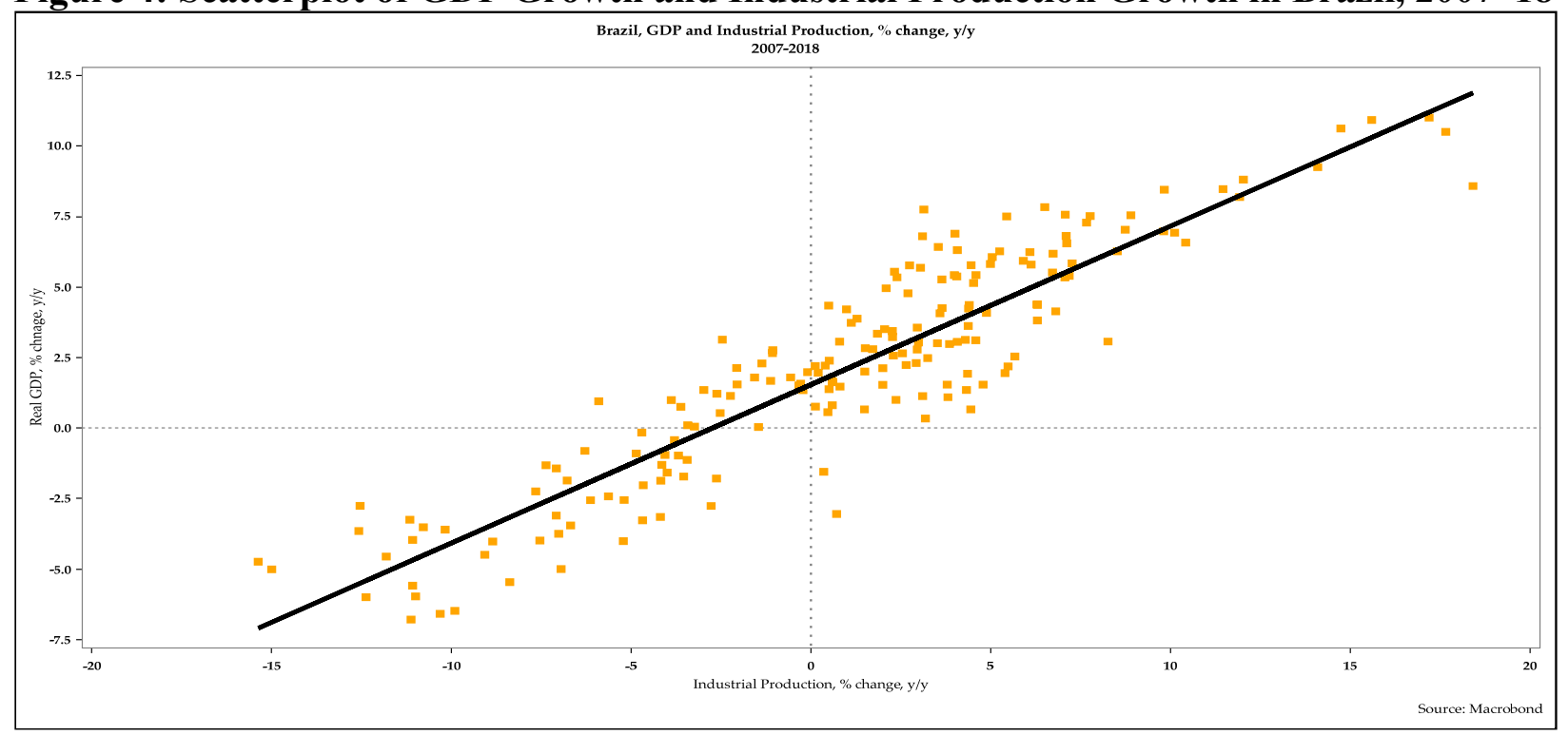


Figure 5 depicts the rates of inflation in Brazil as measured by two different indicators of inflation. These indicators are the consumer price index (CPI) and the general price index (GPI). The GPI is more volatile than the CPI. CPI inflation rose steadily from 2.5 percent in 2007 to over 10 percent by 2016 . However, CPI inflation has declined in recent years and was hovering around 3 percent by late 2018. GPI inflation has been quite volatile.

Figure 5: The Evolution of Inflation in Brazil, 2007-18

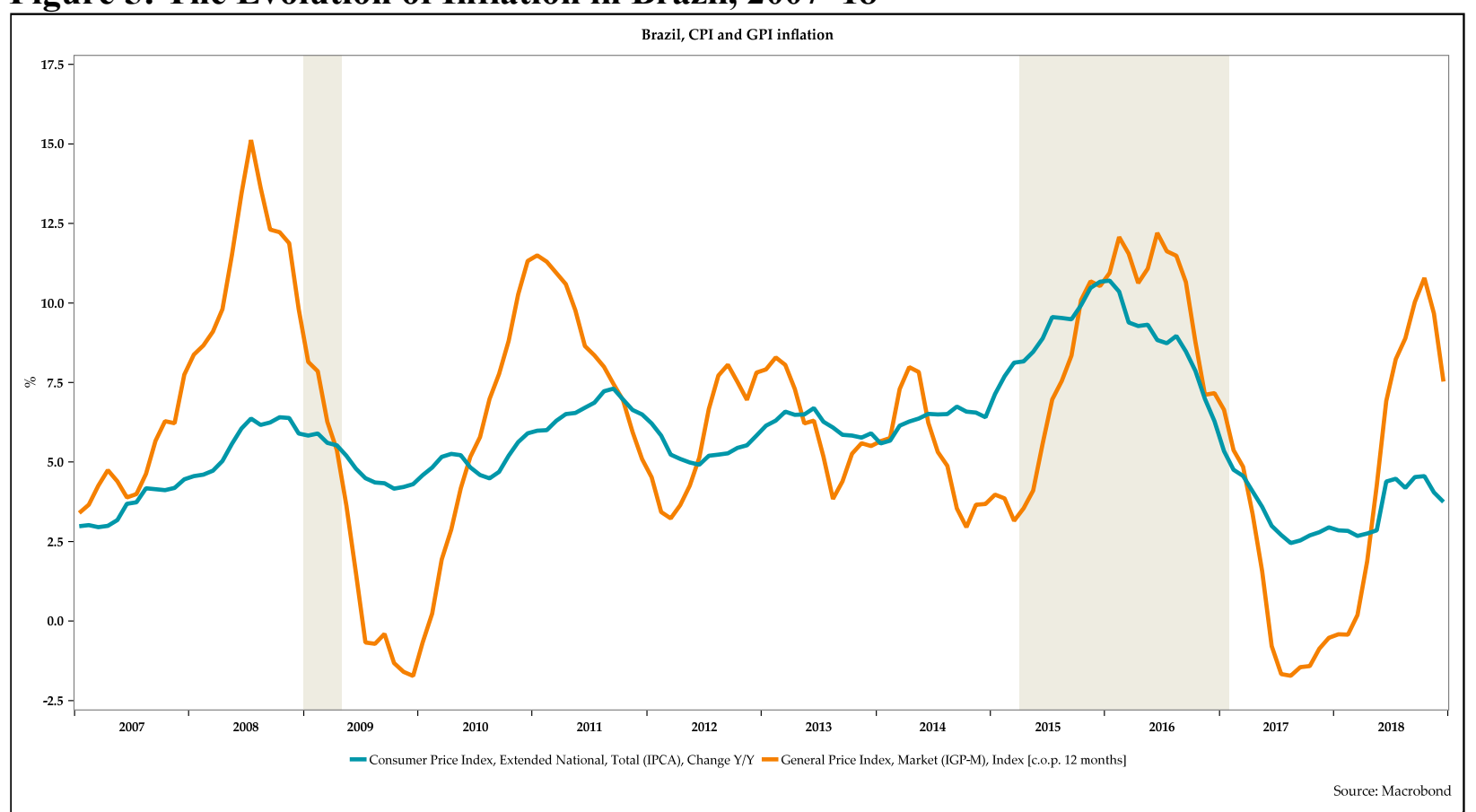

Figure 6 shows the evolution of the Brazilian real. The real depreciated with the global financial crisis. It depreciated ahead of the Brazilian recession in early 2009, but it appreciated from mid2009 until 2011 as the economy recovered. However, since late 2011, the Brazilian real depreciated steadily until early 2016. It appreciated in early 2016 and was stable for more than a year. However, it depreciated again in 2018. 


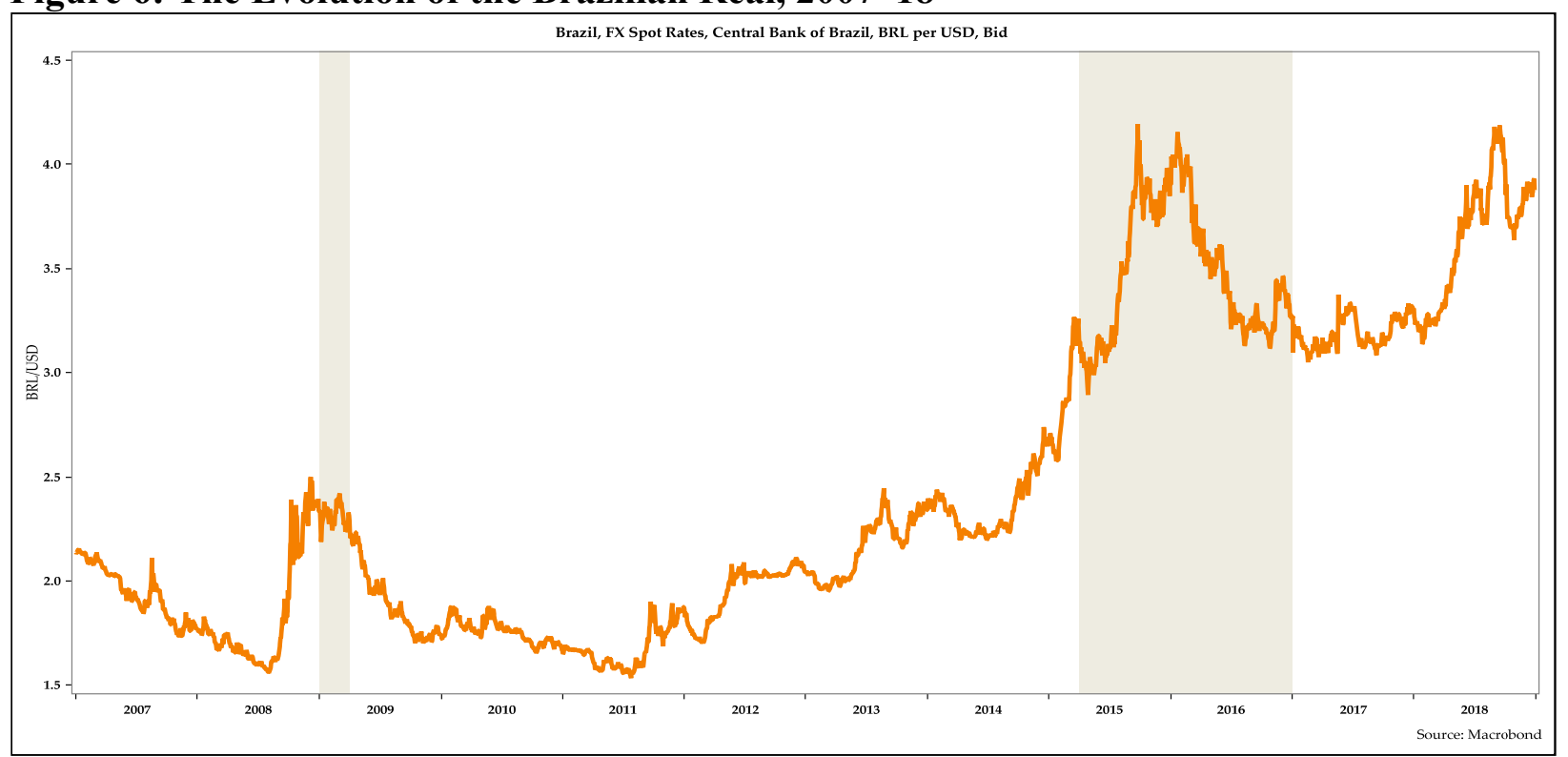

Figure 7 is a scatterplot of the yields of 2-year BGBs and 30-day swaps. Figure 8 is a scatterplot of the year-over-year percentage point changes in yields of 2-year BGBs and 30-day swaps. Figure 9 is a scatterplot of the yields of 10-year BGBs and 30-day swaps. Figure 10 is a scatterplot of the year-over-year percentage point changes in yields of 10-year BGBs and 30-day swaps.

These scatterplots demonstrate some fascinating patterns. First, the yields of long-term BGBs and short-term securities, as measured by swap rates, are positively and tightly correlated. Second, the changes in the yields of long-term BGBs and short-term interest rates, as measured by swap rates, are also positively correlated, though less so than in the levels of the yields. Third, these correlations weaken somewhat as the maturity tenor of the long-term BGBs rise. 
Figure 7: Scatterplot of the Yields of 2-year Brazilian Government Bonds and 30-day Swaps

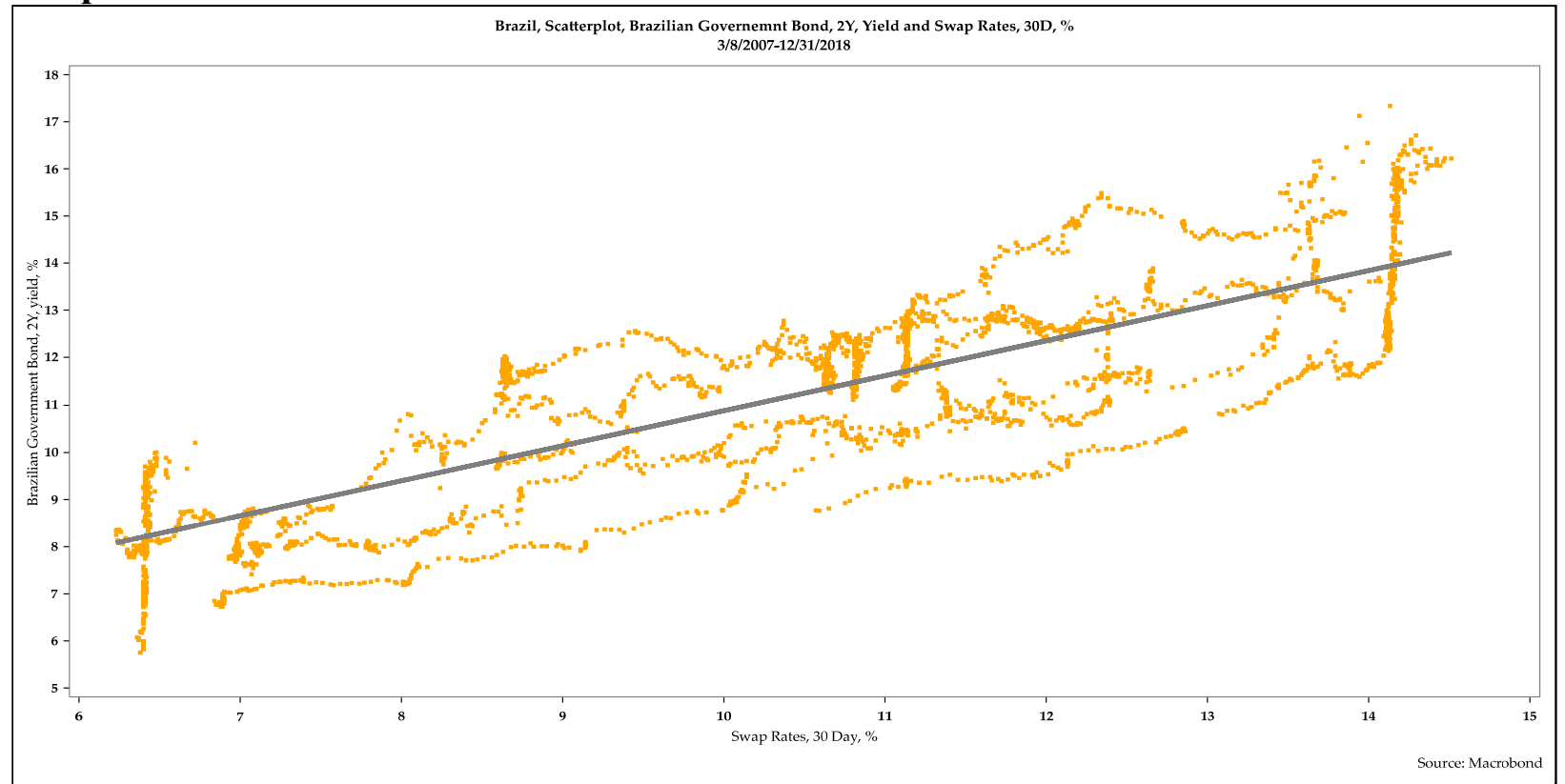

Figure 8: Scatterplot of the Year-Over-Year Percentage Point Changes in the Yields of 2year Brazilian Government Bonds and 30-day Swaps

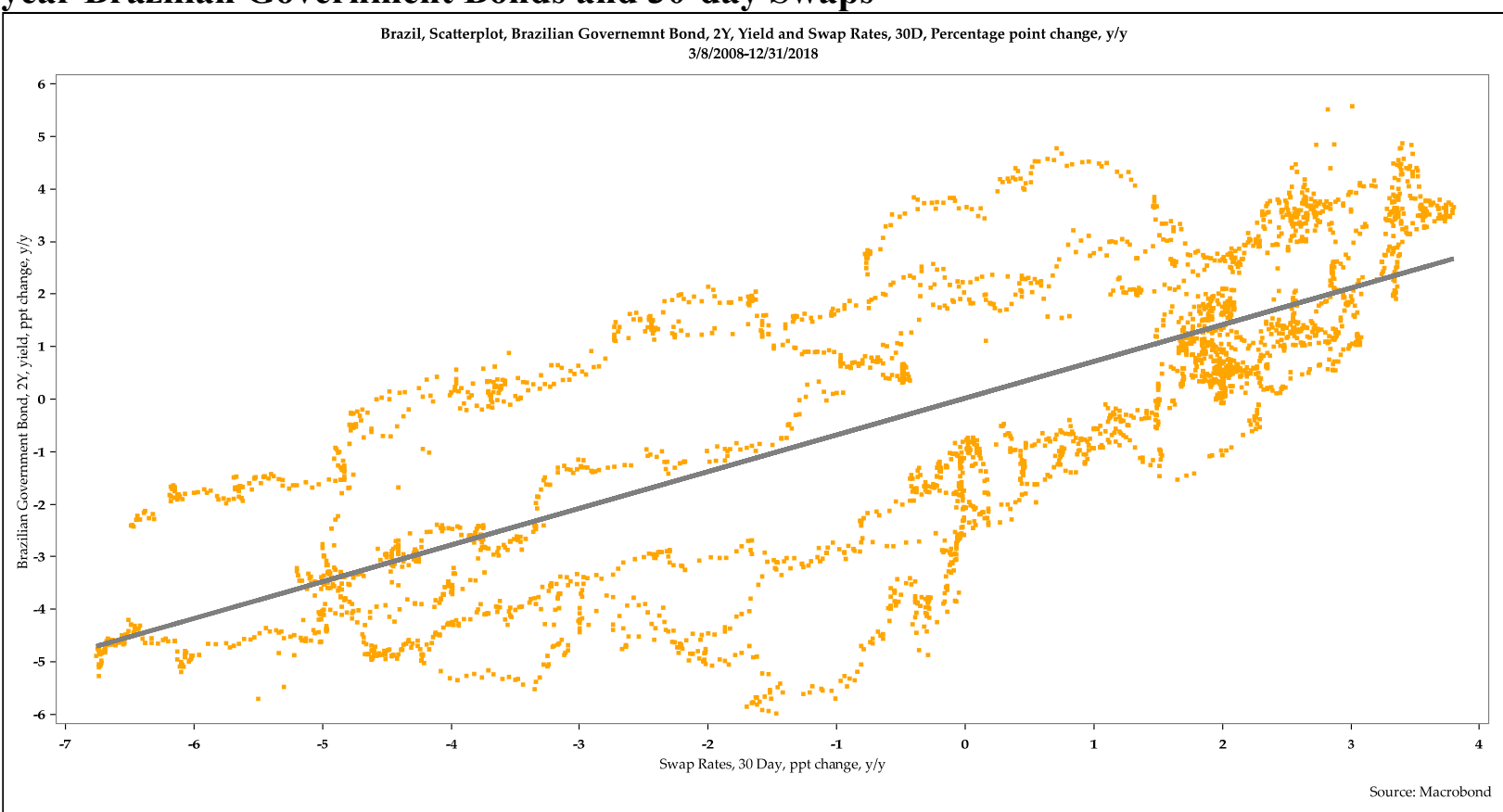


Figure 9: Scatterplot of the Yields of 10-year Brazilian Government Bonds and 30-day Swaps

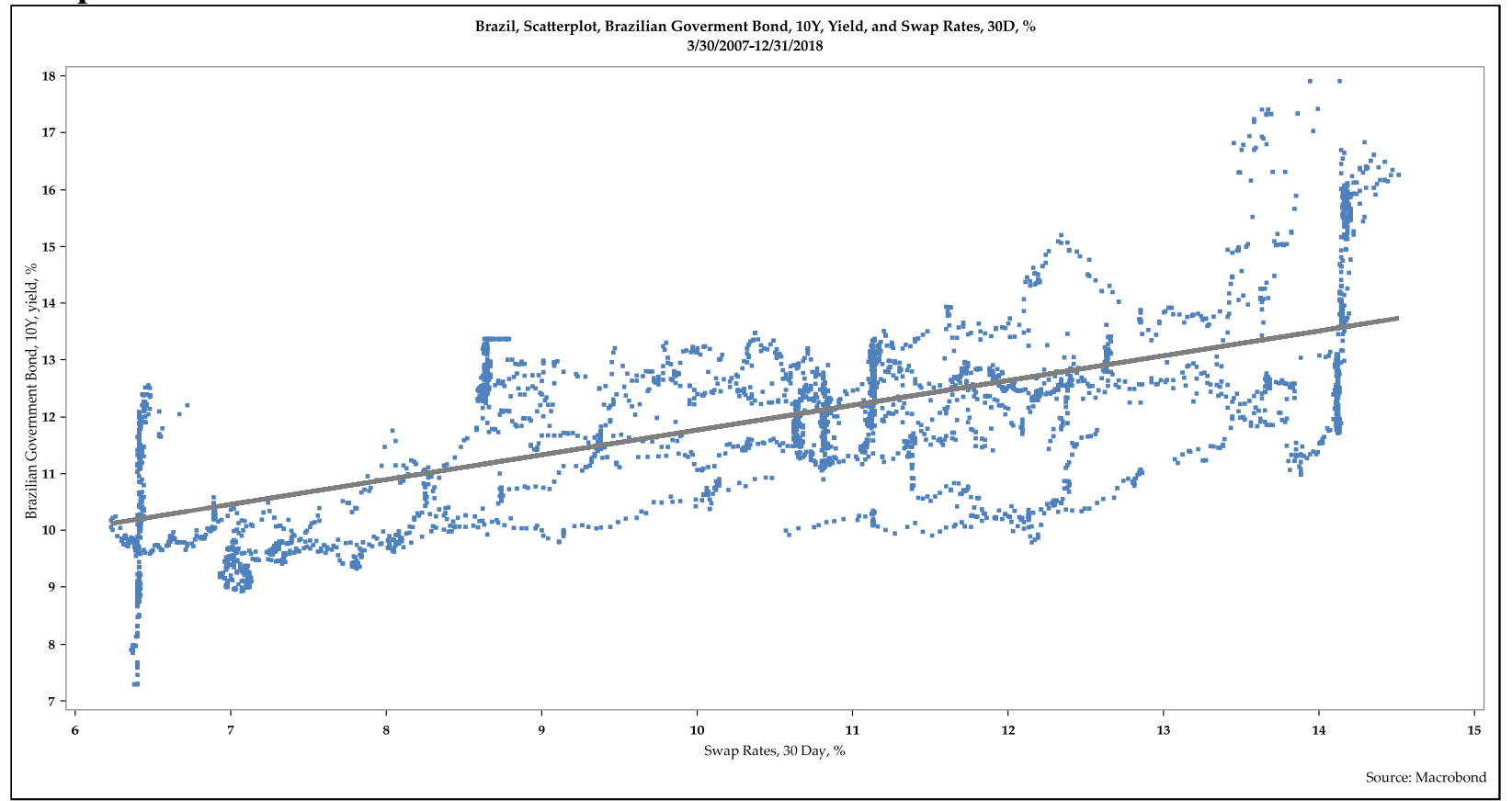

Figure 10: Scatterplot of the Year-Over-Year Percentage Point Changes in the Yields of 10year Brazilian Government Bonds and 30-day Swaps

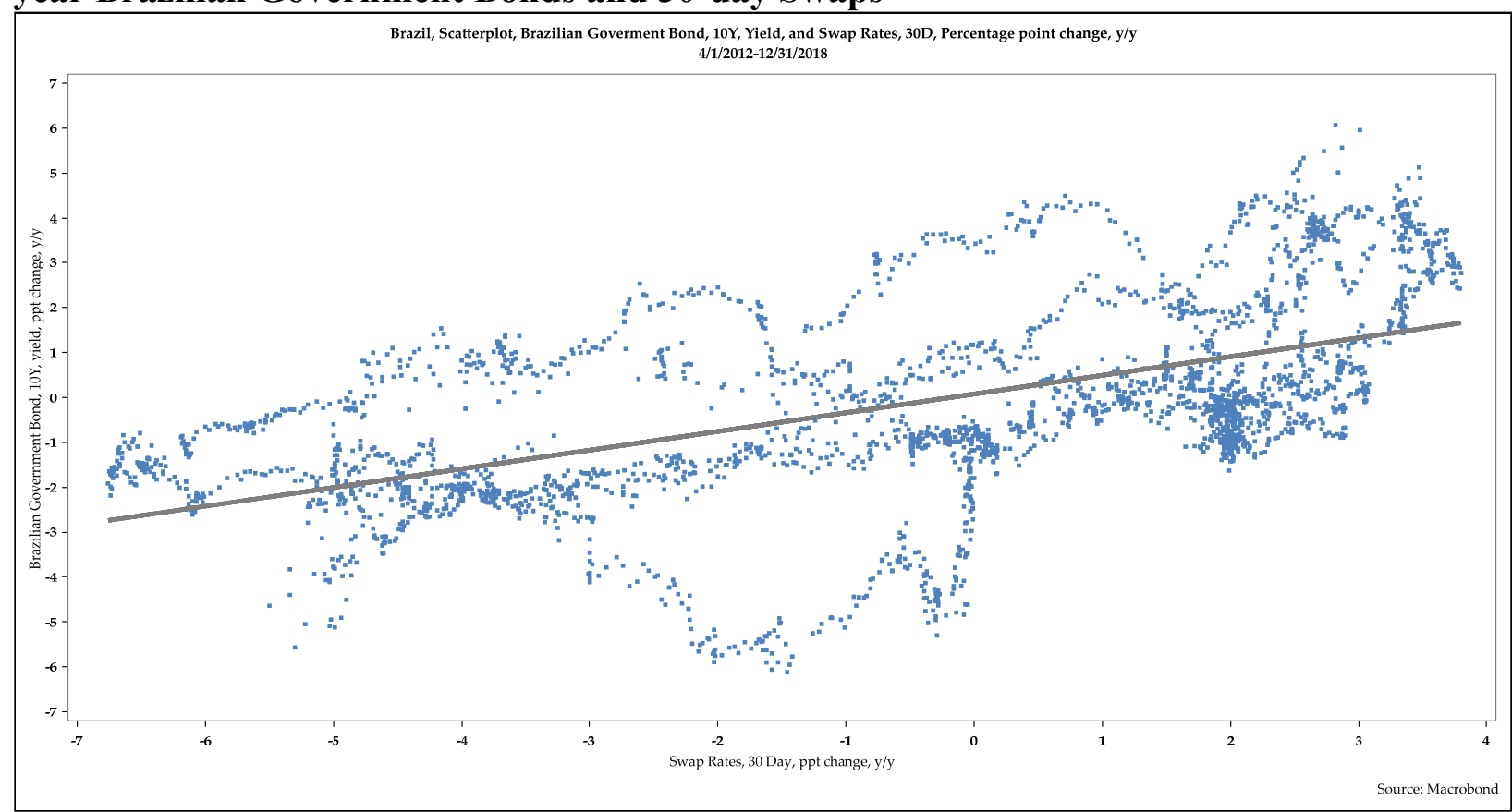




\section{DATA, METHODOLOGY, MODEL, AND EMPIRICAL RESULTS}

\section{Data}

Table 1 provides a summary of the data and the variables used in this paper. The first column gives the variable labels. The second column provides the data description and date ranges of the data. The third column shows the original frequency of data and indicates whether the original data have been converted to monthly frequency. The final column lists the sources of the data.

The variables for the BCB policy rates are the Sistema Especial de Liquidação e de Custódia (SELIC) target rate and the SELIC daily effective rate. The variables for short-term interest rates are yields on 3-month and 6-month Treasury bills and 30-day and 60-day swap rates. The variables for long-term interest rates are the yields of 2-year, 5-year, and 10-year BGBs. The variables for inflation rates are year-over-year percentage changes in the CPI and the GPI. The variables for economic activity are year-over-year changes in the measures of GDP and industrial production. The variable for exchange rate is the spot rate for Brazilian real per US dollar.

Monthly time series data are used in this paper. Some daily time series data have been converted to monthly series. The time series data for most of the variables are from January 2007 to December 2018, which amounts to 12 years of monthly data. 
Table 1: Summary of the Data and the Variables

\begin{tabular}{|c|c|c|c|}
\hline $\begin{array}{l}\text { Variable } \\
\text { labels }\end{array}$ & Data description, date ranges & Frequency & Sources \\
\hline \multicolumn{4}{|l|}{ Policy rates } \\
\hline TARGET & $\begin{array}{l}\text { SELIC target rate, } \% \\
1 / 1 / 2007 \text { to } 12 / 1 / 2018\end{array}$ & $\begin{array}{l}\text { Daily; converted } \\
\text { to monthly }\end{array}$ & $\begin{array}{l}\text { Central Bank of Brazil; } \\
\text { Macrobond }\end{array}$ \\
\hline SELIC & $\begin{array}{l}\text { SELIC daily rate, } \% \text {; } \\
1 / 1 / 2007 \text { to } 12 / 1 / 2018\end{array}$ & $\begin{array}{l}\text { Daily; converted } \\
\text { to monthly }\end{array}$ & $\begin{array}{l}\text { Central Bank of Brazil; } \\
\text { Macrobond }\end{array}$ \\
\hline \multicolumn{4}{|c|}{ Short-term interest rates } \\
\hline TB3M & $\begin{array}{l}\text { Treasury bill, } 3 \text {-month, yield, } \% \text {; } \\
4 / 1 / 2012 \text { to } 12 / 1 / 2018\end{array}$ & $\begin{array}{l}\text { Daily; converted } \\
\text { to monthly }\end{array}$ & $\begin{array}{l}\text { Brazilian Financial and } \\
\text { Capital Markets } \\
\text { Association; Macrobond }\end{array}$ \\
\hline TB6M & $\begin{array}{l}\text { Treasury bill, } 6 \text {-month, yield, } \% \text {; } \\
4 / 1 / 2012 \text { to } 12 / 1 / 2018\end{array}$ & $\begin{array}{l}\text { Daily; converted } \\
\text { to monthly }\end{array}$ & $\begin{array}{l}\text { Brazilian Financial and } \\
\text { Capital Markets } \\
\text { Association; Macrobond } \\
\end{array}$ \\
\hline SWAP30D & $\begin{array}{l}\text { Swap rate, preset rate, } 30 \text { day, } \% \text {; } \\
1 / 1 / 2007 \text { to } 12 / 1 / 2018\end{array}$ & $\begin{array}{l}\text { Daily; converted } \\
\text { to monthly }\end{array}$ & $\begin{array}{l}\text { Central Bank of Brazil; } \\
\text { Macrobond }\end{array}$ \\
\hline SWAP90D & $\begin{array}{l}\text { Swap rate, preset rate, } 90 \text { day, } \% \text {; } \\
1 / 1 / 2007 \text { to } 12 / 1 / 2018\end{array}$ & $\begin{array}{l}\text { Daily; converted } \\
\text { to monthly }\end{array}$ & $\begin{array}{l}\text { Central Bank of Brazil; } \\
\text { Macrobond }\end{array}$ \\
\hline \multicolumn{4}{|c|}{ Government bond yields } \\
\hline GB2Y & $\begin{array}{l}\text { Government bonds, } 2 \text {-year, yield, } \% \text {; } \\
4 / 1 / 2007 \text { to } 12 / 1 / 2018\end{array}$ & $\begin{array}{l}\text { Daily; converted } \\
\text { to monthly }\end{array}$ & $\begin{array}{l}\text { Brazilian Financial and } \\
\text { Capital Markets } \\
\text { Association; Macrobond }\end{array}$ \\
\hline GB10Y & $\begin{array}{l}\text { Government bonds, } 10 \text {-year, yield, } \% \text {; } \\
4 / 1 / 2007 \text { to } 12 / 1 / 2018\end{array}$ & $\begin{array}{l}\text { Daily; converted } \\
\text { to monthly }\end{array}$ & $\begin{array}{l}\text { Brazilian Financial and } \\
\text { Capital Markets } \\
\text { Association; Macrobond }\end{array}$ \\
\hline \multicolumn{4}{|c|}{ Rates of inflation } \\
\hline CPI & $\begin{array}{l}\text { Consumer price index, extended } \\
\text { national, total, } \% \text { change, } y / y \text {; } \\
1 / 1 / 2007 \text { to } 12 / 1 / 2018\end{array}$ & Monthly & $\begin{array}{l}\text { Brazilian Institute of } \\
\text { Geography and Statistics; } \\
\text { Macrobond }\end{array}$ \\
\hline GPI & $\begin{array}{l}\text { General price index, market, index, } \% \\
\text { change, } y / y ; 1 / 1 / 2007 \text { to } 12 / 1 / 2018\end{array}$ & Monthly & $\begin{array}{l}\text { Getulio Vargas Foundation } \\
\text { (Brazilian Institute of } \\
\text { Economy); Macrobond }\end{array}$ \\
\hline \multicolumn{4}{|c|}{ Pace of economic activity } \\
\hline GDP & $\begin{array}{l}\text { Gross domestic product, national, } \\
\text { economic activity, index, SA, \% } \\
\text { change, y/y; 1/1/2007 to } 12 / 1 / 2018\end{array}$ & Monthly & $\begin{array}{l}\text { Central Bank of Brazil; } \\
\text { Macrobond }\end{array}$ \\
\hline IP & $\begin{array}{l}\text { Industrial production, total, calendar } \\
\text { adjusted, index, seasonally adjusted, } \\
\% \text { change, y/y; } 1 / 1 / 2007 \text { to } 12 / 1 / 2018\end{array}$ & Monthly & $\begin{array}{l}\text { Brazilian Institute of } \\
\text { Geography and Statistics; } \\
\text { Macrobond }\end{array}$ \\
\hline \multicolumn{4}{|c|}{ Exchange rate } \\
\hline BRL & $\begin{array}{l}\text { FX spot rate, Brazilian real per U.S. } \\
\text { dollar, bid; } 1 / 1 / 2007 \text { to } 12 / 1 / 2018\end{array}$ & $\begin{array}{l}\text { Daily; converted } \\
\text { to monthly }\end{array}$ & $\begin{array}{l}\text { Central Bank of Brazil; } \\
\text { Macrobond }\end{array}$ \\
\hline
\end{tabular}




\section{Methodology}

In this paper the primary goal is to understand the short-run and long-run relations between BGB yields, the short-term interest rate, and other variables. The vector error correction model (VECM) is used here for estimation. Before undertaking estimation with the VECM, several tasks are undertaken to validate the estimation process. First, tests are undertaken for unit roots, followed by a check for a cointegration between the variables. Second, the optimal lag length for the equations is determined using appropriate statistical technique. Third, the VECM model is applied based on the Johansen (1995) cointegration with optimal lag length. The specification of the behavioral equations presented here is consistent with Keynesian models of government bonds yields, such as Akram and Das (2014, 2015, 2017, 2017, 2019a, 2019b, 2020) and Akram and $\mathrm{Li}(2016,2017,2018,2019,2020)$. These behavioral equations are convenient and readily render themselves to empirical modeling.

The following section describes the results of unit root tests for the variables of interest and their cointegrating behavior.

\section{Unit Root Tests}

Unit root and stationary properties of each of the variables are checked. The augmented DickeyFuller (ADF) (Dickey and Fuller 1979, 1981) and Philips-Perron (PP) (Philips and Perron 1988) tests are to determine the unit root properties of the data. The lag length of the tests is based on the Akaike information criterion (AIC). The generalized ADF test also confirms the lag length choice.

Table 2 presents the results of $\mathrm{ADF}^{4}$ tests. It contains the three types of ADF tests: (1) random walk with drift $(\delta=0)$; (2) random walk with or without drift (none); and (3) random walk without drift ( $\alpha=0, \delta=0$ ). In the ADF test, the null hypothesis is always that the variable has a unit root. Table 2 shows that the null hypothesis of unit root cannot be rejected for most variables at the 1 percent and 5 percent levels of significance. However, the null hypothesis of unit root for

\footnotetext{
${ }^{4}$ If the true model is $Y_{t}=\alpha+Y_{t-1}+u_{t}$, where $u_{t}$ is an independent and identically distributed zero-mean error term, the ADF test is executed. It fits a model of the form $\Delta Y_{t}=\alpha+\beta Y_{t-1}+\delta t+\zeta_{1} \Delta Y_{t-1}+\zeta_{2} \Delta Y_{t-2}+$ $\cdots \ldots \ldots \ldots . \zeta_{k} \Delta Y_{t-k}+\epsilon_{t}$, where $\mathrm{k}$ is the number of lags.
} 
the first difference of most variables can be rejected at the 1 percent and 5 percent levels of significance.

Table 2: Augmented Dickey-Fuller (ADF) Unit Root Test Results

\begin{tabular}{|c|c|c|c|c|c|c|}
\hline Variables & Types & Observations & ADF stat & CV1 & CV5 & Lag \\
\hline GB2Y & Drift & 127 & -1.520 & -2.354 & -1.656 & 1 \\
\hline GB2Y & Trend & 127 & -1.920 & -4.027 & -3.445 & 1 \\
\hline GB2Y & No trend, no drift & 127 & -0.669 & -2.595 & -1.950 & 1 \\
\hline SWAP30D & Drift & 139 & -2.315 & -2.355 & -1.656 & 4 \\
\hline SWAP30D & Trend & 139 & -2.414 & -4.027 & -3.445 & 4 \\
\hline SWAP30D & No trend, no drift & 139 & -0.838 & -2.595 & -1.950 & 4 \\
\hline GPI & Drift & 131 & -2.218 & -2.359 & -1.658 & 12 \\
\hline GPI & Trend & 131 & -2.437 & -4.030 & -3.446 & 12 \\
\hline GPI & No trend, no drift & 131 & -0.938 & -2.596 & -1.950 & 12 \\
\hline GDP & Drift & 131 & -2.207 & -2.359 & -1.658 & 12 \\
\hline GDP & Trend & 131 & -2.325 & -4.030 & -3.446 & 12 \\
\hline GDP & No trend, no drift & 131 & -2.194 & -2.596 & -1.950 & 12 \\
\hline GB10Y & Drift & 136 & -2.306 & -2.355 & -1.657 & 4 \\
\hline GB10Y & Trend & 136 & -2.649 & -4.028 & -3.445 & 4 \\
\hline GB10Y & No trend, no drift & 136 & -0.602 & -2.595 & -1.950 & 4 \\
\hline$\Delta \mathrm{GB} 2 \mathrm{Y}$ & Drift & 126 & -4.985 & -2.355 & -1.656 & 2 \\
\hline$\Delta \mathrm{GB} 2 \mathrm{Y}$ & Trend & 126 & -5.029 & -4.028 & -3.445 & 2 \\
\hline$\Delta \mathrm{GB} 2 \mathrm{Y}$ & No trend, no drift & 126 & -4.988 & -2.595 & -1.950 & 2 \\
\hline$\triangle \mathrm{SWAP30D}$ & Drift & 129 & -3.702 & -2.354 & -1.656 & 3 \\
\hline$\triangle$ SWAP30D & Trend & 129 & -3.723 & -4.027 & -3.445 & 3 \\
\hline$\triangle \mathrm{SWAP30D}$ & No trend, no drift & 129 & -3.694 & -2.595 & -1.950 & 3 \\
\hline$\Delta \mathrm{GPI}$ & Drift & 129 & -3.846 & -2.354 & -1.656 & 2 \\
\hline$\Delta \mathrm{GPI}$ & Trend & 129 & -3.827 & -4.027 & -3.445 & 2 \\
\hline$\Delta \mathrm{GPI}$ & No-trend, no drift & 129 & -3.870 & -2.595 & -1.950 & 2 \\
\hline$\Delta \mathrm{GDP}$ & Drift & 129 & -5.819 & -2.354 & -1.656 & 1 \\
\hline$\Delta \mathrm{GDP}$ & Trend & 129 & -5.799 & -4.026 & -3.445 & 1 \\
\hline$\Delta \mathrm{GDP}$ & No trend, no drift & 129 & -5.835 & -2.595 & -1.950 & 1 \\
\hline$\Delta \mathrm{GB} 10 \mathrm{Y}$ & Drift & 126 & -9.535 & -2.354 & -1.656 & 1 \\
\hline$\Delta \mathrm{GB} 10 \mathrm{Y}$ & Trend & 126 & -9.568 & -4.027 & -3.445 & 1 \\
\hline$\Delta \mathrm{GB} 10 \mathrm{Y}$ & No trend, no drift & 126 & -9.569 & -2.595 & -1.950 & 1 \\
\hline
\end{tabular}

Notes: ADF stat presents the calculated statistic for the variables following the ADF model with the optimal lag length. Lag length is selected based on AIC. CV1 and CV5 presents critical values for the 1 percent and 5 percent levels of significance, respectively. Here drift means that the process under the null hypothesis is a random walk with drift (unit root with drift), so the population value of $\alpha$ is non-zero. Trend means the process under the null hypothesis is a unit root with or without drift so that $\alpha$ is unrestricted and includes a time trend in the regression. No trend, no drift means that the process under the null hypothesis is a unit root without drift; it fits without any constant term $\alpha$ and any time trend $\delta t$. 
Table 3 presents the results of the $\mathrm{PP}^{5}$ tests. It contains two types of PP tests: (1) random walk without drift ( $\alpha=0, \delta=0)$; and (2) random walk with or without drift (none). The null hypothesis is that the variable contains a unit root, and the alternative is that the variable was generated by a stationary process. Table 3 shows the null hypothesis of unit root cannot be rejected for most variables at the 1 percent and 5 percent levels of confidence. However, the null hypothesis of unit root for the first difference of most variables can be rejected at the 1 percent and 5 percent levels of confidence.

\footnotetext{
${ }^{5}$ As the ordinary OLS regression may have serial correlations; in order to account for this, the ADF test uses lags of the variable. Phillips and Perron (1988) proposed two alternative statistics, which can be viewed as Dickey-Fuller statistics that are more robust to serial correlation.
} 
Table 3: Phillips-Perron (PP) Unit Root Tests

\begin{tabular}{|c|c|c|c|c|c|c|}
\hline Variable & Type & Observations & PP stat & CV1 & CV5 & Lag \\
\hline GB2Y & $\begin{array}{l}\text { No trend, no } \\
\text { drift }\end{array}$ & 140 & -0.719 & -2.595 & -1.950 & 4 \\
\hline GB2Y & Trend & 140 & -1.998 & -4.027 & -3.445 & 4 \\
\hline SWAP30D & $\begin{array}{l}\text { No trend, no } \\
\text { drift }\end{array}$ & 143 & -1.100 & -2.594 & -1.950 & 4 \\
\hline SWAP30D & Trend & 143 & -1.407 & -4.026 & -3.444 & 4 \\
\hline GPI & $\begin{array}{l}\text { No trend, no } \\
\text { drift }\end{array}$ & 143 & -1.262 & -2.594 & -1.950 & 4 \\
\hline GPI & Trend & 143 & -2.707 & -4.026 & -3.444 & 4 \\
\hline GDP & $\begin{array}{l}\text { No trend, no } \\
\text { drift }\end{array}$ & 143 & -2.235 & -2.594 & -1.950 & 4 \\
\hline GDP & Trend & 143 & -2.469 & -4.026 & -3.444 & 4 \\
\hline GB10Y & $\begin{array}{l}\text { No trend, no } \\
\text { drift }\end{array}$ & 140 & -0.493 & -2.595 & -1.950 & 4 \\
\hline GB10Y & Trend & 140 & -2.948 & -4.027 & -3.445 & 4 \\
\hline$\Delta \mathrm{GB} 2 \mathrm{Y}$ & $\begin{array}{l}\text { No trend, no } \\
\text { drift }\end{array}$ & 139 & -10.42 & -2.595 & -1.950 & 4 \\
\hline$\Delta \mathrm{GB} 2 \mathrm{Y}$ & Trend & 139 & -10.42 & -4.027 & -3.445 & 4 \\
\hline$\triangle$ SWAP30D & $\begin{array}{l}\text { No-trend, no } \\
\text { drift }\end{array}$ & 142 & -4.139 & -2.594 & -1.950 & 4 \\
\hline$\triangle$ SWAP30D & Trend & 142 & -4.169 & -4.026 & -3.444 & 4 \\
\hline$\Delta \mathrm{GPI}$ & $\begin{array}{l}\text { No trend, no } \\
\text { drift }\end{array}$ & 142 & -5.114 & -2.594 & -1.950 & 4 \\
\hline$\Delta \mathrm{GPI}$ & Trend & 142 & -5.070 & -4.026 & -3.444 & 4 \\
\hline$\Delta \mathrm{GDP}$ & $\begin{array}{l}\text { No trend, no } \\
\text { drift }\end{array}$ & 142 & -10.09 & -2.594 & -1.950 & 4 \\
\hline$\Delta \mathrm{GDP}$ & Trend & 142 & -10.05 & -4.026 & -3.444 & 4 \\
\hline$\Delta \mathrm{GB} 10 \mathrm{Y}$ & $\begin{array}{l}\text { No trend, no } \\
\text { drift }\end{array}$ & 139 & -11.75 & -2.595 & -1.950 & 4 \\
\hline$\Delta \mathrm{GB} 10 \mathrm{Y}$ & Trend & 139 & -11.73 & -4.027 & -3.445 & 4 \\
\hline
\end{tabular}

Notes: PP statistics presents the calculated statistic for the variables following the PP model with the optimal lag length. Lag length is selected based on the AIC. CV1 and CV5 present critical values for the 1 percent and 5 percent levels of significance, respectively. 


\section{Lag Length and Cointegration Tests}

The cointegration test is applied to determine whether there really is a long-run (or cointegrating) relationship among the variables. The optimal lag length is selected for the cointegration tests. Table 4 reports the log-likelihood (LL), likelihood ratio (LR), final prediction error (FPE), the Akaike information criterion (AIC), Schwarz's Bayesian information criterion (SBIC), and the Hannan and Quinn information criterion (HQIC) lag-order selection statistics for a series of vector autoregressions of order 1 through a requested maximum lag. For a given lag $\mathrm{p}$, the LR test compares a VAR with $p$ lags to one with $p-1$ lags. The null hypothesis is that all the coefficients on the p-th lags of the endogenous variables are zero. To use this sequence of LR tests to select a lag order, the results of the test for the model with the most lags, which is at the bottom of the table, were carefully examined. An "*” appears next to the LR statistic indicating the optimal lag. For the remaining statistics, the lag with the smallest value is the order selected by that criterion. An “*” indicates the optimal lag. This paper uses the AIC as the selection criteria for finding the optimal lag length. 
Table 4: Lag Length Selection

\begin{tabular}{|c|c|c|c|c|c|c|}
\hline Lag & $\mathbf{L L}$ & LR & FPE & AIC & HQIC & SBIC \\
\hline \multicolumn{7}{|c|}{ Part A: Variables: GB2Y, SWAP30D GPI, GDP } \\
\hline 0 & $-1,264.847$ & & $1,302.189$ & 18.523 & 18.558 & 18.609 \\
\hline 1 & -498.880 & 1531.934 & 0.023 & 7.575 & 7.748 & 8.001 \\
\hline 2 & -428.421 & 140.918 & 0.010 & 6.780 & $7.092 *$ & $7.547 *$ \\
\hline 3 & -409.863 & 37.117 & $0.010 *$ & $6.743 *$ & 7.193 & 7.851 \\
\hline 4 & -394.391 & $30.944 *$ & 0.010 & 6.750 & 7.339 & 8.200 \\
\hline \multicolumn{7}{|c|}{ Part B: Variables: GB2Y, SWAP30D, GPI } \\
\hline 0 & -898.855 & & 104.808 & 13.166 & 13.192 & 13.230 \\
\hline 1 & -300.570 & $1,196.570$ & 0.019 & 4.563 & 4.667 & 4.819 \\
\hline 2 & -230.451 & 140.239 & 0.008 & 3.671 & $3.853 *$ & $4.118^{*}$ \\
\hline 3 & -218.957 & 22.987 & 0.008 & 3.634 & 3.894 & 4.274 \\
\hline 4 & -209.224 & $19.466^{*}$ & $0.008 *$ & $3.624 *$ & 3.962 & 4.455 \\
\hline \multicolumn{7}{|c|}{ Part C: Variables: GB10Y, SWAP30D, GPI, GDP } \\
\hline 0 & $-1,270.875$ & & $1,421.983$ & 18.611 & 18.646 & 18.697 \\
\hline 1 & -555.380 & $1,430.990$ & 0.052 & 8.400 & 8.573 & 8.826 \\
\hline 2 & -464.139 & 182.481 & 0.017 & 7.301 & $7.613 *$ & $8.069 *$ \\
\hline 3 & -440.188 & 47.903 & $0.016^{*}$ & $7.185^{*}$ & 7.636 & 8.294 \\
\hline 4 & -424.824 & $30.728 *$ & 0.016 & 7.195 & 7.783 & 8.644 \\
\hline \multicolumn{7}{|c|}{ Part D: Variables: GB10Y, SWAP30D, GPI } \\
\hline 0 & -897.485 & & 102.734 & 13.146 & 13.172 & 13.210 \\
\hline 1 & -362.876 & $1,069.218$ & 0.048 & 5.473 & 5.577 & 5.728 \\
\hline 2 & -266.366 & 193.020 & 0.013 & 4.195 & 4.377 & $4.643^{*}$ \\
\hline 3 & -251.123 & $30.486^{*}$ & $0.012 *$ & $4.104 *$ & $4.364 *$ & 4.743 \\
\hline 4 & -242.926 & 16.395 & 0.012 & 4.116 & 4.454 & 4.947 \\
\hline
\end{tabular}

Table 4 presents various measures of lag length selection criteria. It is evident from table 4 (part A) that based on the AIC the optimal lag length is three. However, HQIC and the SIBC method suggested two lags. Similarly, in part B, GDP was dropped from the VAR list. The remaining three variables with an optimal lag length of four (based on AIC) were used. In part C, GB2Y was replaced with GB10Y, keeping other variables the same as parts A and B. Following the AIC, three lags were used both in parts C and D. 
Following the optimal lag length, the cointegration relationship is defined based on Johansen (1995). ${ }^{6}$ If all variables in $Y_{t}$ are $\mathrm{I}(1)$, the matrix $\Pi$ has rank $0 \leq r<K$, where $r$ is the number of linearly independent cointegrating vectors. If the variables are cointegrated $(r>0)$, the VAR in first differences is misspecified, as it excludes the error correction term.

Table 5 reports the rank test for the cointegrating equation. Table 5, part A, shows the Johansen (1995) test statistics for rank test. The first is Johansen's "trace" statistic method. The second is the "maximum eigenvalue" statistic method. According to the trace statistic test, for any given value of $r$, large values of the trace statistic are evidence against the null hypothesis that there are $\mathrm{r}$ or fewer cointegrating relations in the VECM. In table 5, each row represents one hypothesis test. For each test, it reports the maximum rank under the null, the number of parameters estimated, the log-likelihood, the r-th eigenvalue, the trace statistic, and a 5 percent critical value for the trace statistic. Trace statistic confirms that here $r=1$, which implies there is only one cointegrating equation. ${ }^{7}$ In this example, the trace statistic at $r=0$ of 69.417 exceeds its critical value of 62.990. Hence, the null hypothesis of no cointegrating equations is rejected. Similarly, the trace statistic at $r=1$ of 35.091 is less than its critical value of 42.440 . Hence, the null hypothesis that there are one or fewer cointegrating equations cannot be rejected. The "*" by the trace statistic at $r=1$ indicates that this is the value of $r$ selected by Johansen's multiple-trace test procedure. The eigenvalue shown in the last line of output computes the trace statistic in the

\footnotetext{
${ }^{6}$ Consider a VAR with $\mathrm{p}$ lags as follows:

$Y_{t}=v+A_{1} Y_{t-1}+A_{2} Y_{t-2}+\cdots \ldots \ldots \ldots+A_{p} Y_{t-p}+\epsilon_{t}$

where $Y_{t}$ is a $\mathrm{K} \times 1$ vector of variables, $\mathrm{v}$ is a $\mathrm{K} \times 1$ vector of parameters, $A_{1}-A_{p}$ are $\mathrm{K} \times \mathrm{K}$ matrices of parameters, and $\varepsilon_{t}$ is a $\mathrm{K} \times 1$ vector of disturbances. $\varepsilon_{t}$ has mean 0 , has covariance matrix $\Sigma$, and is i.i.d. normal over time. Any $\operatorname{VAR}(\mathrm{p})$ can be rewritten as a VECM in the following manner:

$\Delta Y_{t}=v+\Pi Y_{t-1}+\sum_{i=1}^{p-1} \Gamma_{i} \Delta Y_{t-i}+\epsilon_{t}$

where $\Pi=\sum_{j=1}^{j=p} A_{j}-I_{k}$ and $\Gamma_{i}=-\sum_{j=i+1}^{j=p} A_{j}$

${ }^{7}$ Johansen (1995) gives five different specifications to test the number of cointegrating equations. As there are no specific rules to select one of them as the best strategy, all the specifications were examined. The results in table 3 present the restricted trend term.
} 
preceding line. When max statistic is lower than the 5 percent critical value, the null hypothesis is rejected. ${ }^{8}$

In table 5 (part B), the variable GDP is dropped. The trace statistic shows that $r=1$, which implies that there is one cointegrating equation. Similarly, in parts C and D, the GB10Y trace statistic suggests that there is one cointegrating relationship for each model.

\footnotetext{
${ }^{8}$ The alternative hypothesis of the trace statistic is that the number of cointegrating equations is strictly larger than the number $r$ assumed under the null hypothesis. Instead, a given $r$ under the null hypothesis can be used and this could be tested against the alternative that there are $r+1$ cointegrating equations.
} 
Table 5: Rank of the Cointegration Order (Johansen [1995] test)

\begin{tabular}{|c|c|c|c|c|c|}
\hline \multicolumn{6}{|c|}{ Part A: Variables: GB2Y SWAP30D GPI GDP } \\
\hline Maximum rank & Parms & LL & Eigenvalue & Trace statistic & $5 \%$ critical value \\
\hline 0 & 36 & -436.017 & & 69.417 & 62.990 \\
\hline 1 & 44 & -418.856 & 0.220 & $35.095 *$ & 42.440 \\
\hline 2 & 50 & -410.124 & 0.119 & 17.631 & 25.320 \\
\hline 3 & 54 & -403.415 & 0.093 & 4.213 & 12.250 \\
\hline 4 & 56 & -401.308 & 0.030 & & \\
\hline Maximum rank & Parms & LL & Eigenvalue & Max statistic & $5 \%$ critical value \\
\hline 0 & 36 & -436.017 & & 34.322 & 31.460 \\
\hline 1 & 44 & -418.856 & 0.220 & 17.464 & 25.540 \\
\hline 2 & 50 & -410.124 & 0.119 & 13.418 & 18.960 \\
\hline 3 & 54 & -403.415 & 0.093 & 4.213 & 12.520 \\
\hline 4 & 56 & -401.308 & 0.030 & & \\
\hline \multicolumn{6}{|c|}{ Part B: Variables: GB2Y, SWAP30D, GPI } \\
\hline Maximum rank & Parms & $\mathrm{LL}$ & Eigenvalue & Trace statistic & $5 \%$ critical value \\
\hline 0 & 21 & -239.211 & & 48.807 & 42.440 \\
\hline 1 & 27 & -224.961 & 0.187 & $20.3069 *$ & 25.320 \\
\hline 2 & 31 & -216.926 & 0.110 & 4.237 & 12.250 \\
\hline 3 & 33 & -214.807 & 0.030 & & \\
\hline Maximum rank & Parms & $\mathrm{LL}$ & Eigenvalue & Max statistic & $5 \%$ critical value \\
\hline 0 & 21 & -239.211 & & 28.500 & 25.540 \\
\hline 1 & 27 & -224.961 & 0.187 & 16.070 & 18.960 \\
\hline 2 & 31 & -216.926 & 0.110 & 4.237 & 12.520 \\
\hline 3 & 33 & -214.807 & 0.030 & & \\
\hline \multicolumn{6}{|c|}{ Part C: GB10Y, SWAP30D, GPI, GDP, } \\
\hline Maximum rank & Parms & LL & Eigenvalue & Trace statistic & $5 \%$ critical value \\
\hline 0 & 36 & -466.647 & & 64.868 & 62.990 \\
\hline 1 & 44 & -451.625 & 0.196 & $34.824 *$ & 42.440 \\
\hline 2 & 50 & -442.863 & 0.119 & 17.300 & 25.320 \\
\hline 3 & 54 & -436.494 & 0.088 & 4.561 & 12.250 \\
\hline 4 & 56 & -434.214 & 0.033 & & \\
\hline Maximum rank & Parms & LL & Eigenvalue & Max statistic & $5 \%$ critical value \\
\hline 0 & 36 & -466.647 & & 30.044 & 31.460 \\
\hline 1 & 44 & -451.625 & 0.196 & 17.524 & 25.540 \\
\hline 2 & 50 & -442.863 & 0.119 & 12.739 & 18.960 \\
\hline 3 & 54 & -436.494 & 0.088 & 4.561 & 12.520 \\
\hline 4 & 56 & -434.214 & 0.033 & & \\
\hline
\end{tabular}

\begin{tabular}{|c|c|c|c|c|c|}
\hline \multicolumn{6}{|c|}{ Part D: GB10Y, SWAP30D, GPI } \\
\hline Maximum rank & Parms & LL & Eigenvalue & trace statistic & $5 \%$ critical value \\
\hline 0 & 21 & -271.953 & & 46.222 & 42.440 \\
\hline 1 & 27 & -258.807 & 0.173 & $19.929 *$ & 25.320 \\
\hline 2 & 31 & -251.236 & 0.104 & 4.787 & 12.250 \\
\hline 3 & 33 & -248.843 & 0.034 & & \\
\hline
\end{tabular}

\begin{tabular}{crrrrr}
\hline Maximum rank & Parms & LL & Eigenvalue & Max statistic & 5\% critical value \\
\hline 0 & 21 & -271.953 & & 26.293 & 25.540 \\
1 & 27 & -258.807 & 0.173 & 15.141 & 18.960 \\
2 & 31 & -251.236 & 0.104 & 4.787 & 12.520 \\
3 & 33 & -248.843 & 0.034 & & \\
\hline
\end{tabular}




\section{Vector Error Correction Model (VECM)}

VECMs are appropriate when variables are stationary in their first differences while nonstationary in their levels. From the unit root tests, the results show that these series are nonstationary in their levels but are stationary in their first differences. Hence, these variables are integrated of order I(1).

VECMs can be used to estimate the short-term and long-term relationships between variables. Moreover, the adjustment factors from short-term to long-term dynamics can also be estimated. The next three tables explain the results of the VECM model. The analysis is based on the longrun relationship, short-run relationship, and the adjustment from short-run deviation to long-run equilibrium.

Table 6 shows the estimation results from the VECM model. ${ }^{9}$ It reveals the long-term relationship between the variables. Table 6 presents the long-term relationship based on equations (1) and (2):

$$
\Delta Z_{t}=\alpha \beta^{\prime} Z_{t-1}+\sum_{i=1}^{p-1} \Gamma_{i} \Delta Z_{t-i}+v+\delta t+\epsilon_{t}
$$

where $Z=[G B 2 Y, S W A P 30 D, G P I, G D P]^{\prime}$

$$
\Delta Z_{t}=\alpha \beta^{\prime} Z_{t-1}+\sum_{i=1}^{p-1} \Gamma_{i} \Delta Z_{t-i}+v+\delta t+\epsilon_{t}
$$

where $Z=[G B 2 Y, S W A P 30 D, G P I]^{\prime}$

From the cointegrating rank test (see table 5, part A), equation (1) has a rank of 1. This implies that there is one error correction equation. It is evident that all these variables are statistically significant, which says that GB2Y has a long-term causality with SWAP30D, GPI, and GDP. The result indicates that in the long term, there is a positive relationship between swap rates (30

\footnotetext{
${ }^{9}$ Actually, several VECM models are executed because the VECM models are highly depended on the number of lags, trend term, and constant. From the Johansen procedure of rank test, five different types of tests are conducted. Most of the specifications suggested one cointegration equation in the long run.
} 
days) and government bond yields (2-year yield). This implies that if the SWAP30D rate increases, then the government bond yields for two-year maturity rates also increases. There is negative association between GDP and GPI, which indicates that if GDP or GPI increase, then government bonds yields decrease. Column 2 reports the result excluding GDP from the regression. It is evident from the table that even if GDP is excluded from the analysis, then all the variables are statistically significant, and that model fits well. Interestingly, after dropping the variable GDP, the SWAP30D rate has a larger coefficient compared to the previous model.

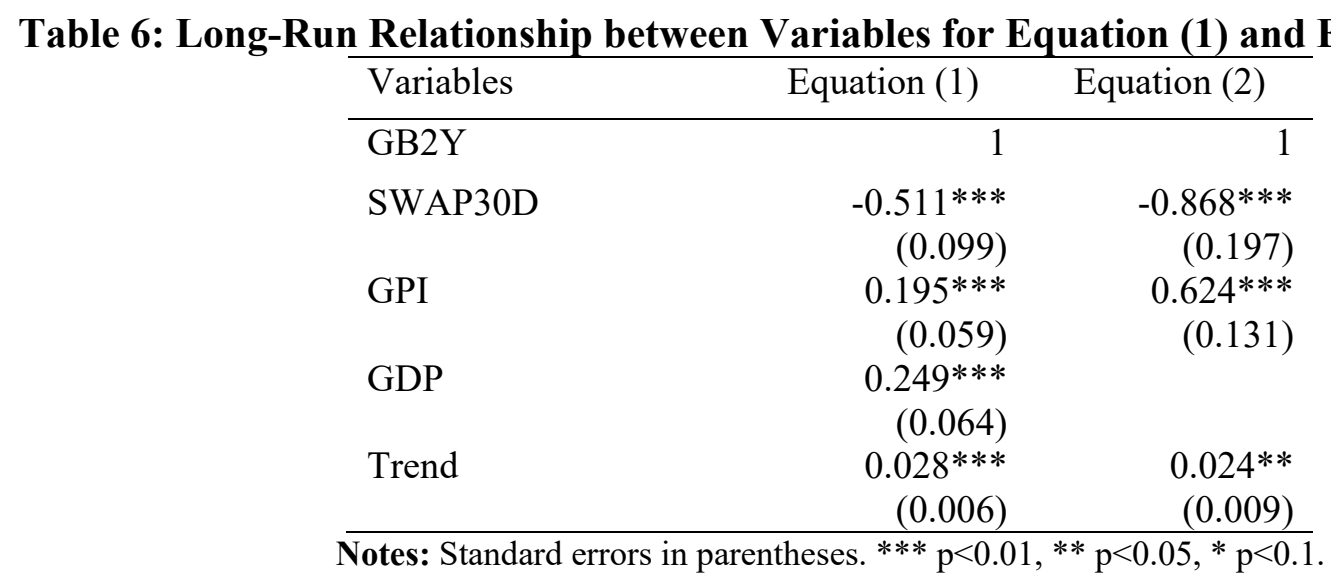

In table 7, the dependent variable is GB10. Column 2 shows the result based on equation (3), while column 3 shows the result based on equation (4). The swap rate is statistically insignificant, though it has the expected sign. Here, GDP, GPI, and the linear trend variables are statistically significant. In column 3, even after dropping GDP from the regression, the swap rate is still statistically insignificant.

$$
\Delta Z_{t}=\alpha \beta^{\prime} Z_{t-1}+\sum_{i=1}^{p-1} \Gamma_{i} \Delta Z_{t-i}+v+\delta t+\epsilon_{t}
$$

where $Z=[G B 10 Y, S W A P 30 D, G P I, G D P]^{\prime}$

$$
\Delta Z_{t}=\alpha \beta^{\prime} Z_{t-1}+\sum_{i=1}^{p-1} \Gamma_{i} \Delta Z_{t-i}+v+\delta t+\epsilon_{t}
$$

where $Z=[G B 10 Y, S W A P 30 D, G P I]^{\prime}$ 
Table 7: Long-Run Relationship between Variables for Equation (3) and Equation (4)

\begin{tabular}{lrr}
\hline Variables & Equation (3) & \multicolumn{1}{c}{ Equation (4) } \\
\hline GB10Y & 1 & 1 \\
SWAP30D & -0.045 & -0.369 \\
& $(0.178)$ & $(0.233)$ \\
GPI & $0.357^{* * *}$ & $0.586^{* * *}$ \\
& $(0.106)$ & $(0.150)$ \\
GDP & $0.425^{* * *}$ & \\
& $(0.115)$ & \\
Trend & $0.040^{* * *}$ & $0.024^{* *}$ \\
& $(0.006)$ & $(0.011)$ \\
\hline Notes: Standard errors in parentheses. ${ }^{* *} \mathrm{p}<0.01,{ }^{* *} \mathrm{p}<0.05, * \mathrm{p}<0.1$
\end{tabular}

Table 8 presents the speed of adjustments to the long-term equilibrium from the short-term deviation. It is evident that GB2Y is statistically significant with the expected (negative) sign in columns 2 and 5 and row 2 (with error correction). This implies that short-term deviation from the long-term equilibrium is adjusting by 0.191 percentage points and 0.23 percentage points in each month, respectively. It is also evident that SWAP30D and GPI are not statistically significant, but GDP is statistically significant with the expected sign. Thus, the GDP growth rate has a positive effect on long-term convergence.

In order to find the short-term causality betwen variables, it is useful to look at the lag coefficients for each variable. In table 8, for the GB2Y (column 2 and 5), none of the lags of GB2Y are statistically significant, but both of the lags of SWAP30D are statistically significant. Apart from that, the first lag of both the GPI and GDP variable is statistically insignificant, whereas the second lag is statistically significant. Therefore, SWAP30D, GPI, and GDP have short-run causality with GB2Y after the first lag. It implies that an increase in the previous month's GB2Y yield does not influence the current month's GB2Y increase. However, an increase in the last month's SWAP30D is associated with an increase in current month's GB2Y yield. Similarly, a GDP and GPI increase with a two-month lag increases the current month's GB2Y yield. 
Table 8: Speed of Adjustment and Short-Run Relationship to VECM for Equation (1) and Equation (2)

\begin{tabular}{|c|c|c|c|c|c|c|c|}
\hline \multirow[b]{2}{*}{ VARIABLES } & \multicolumn{3}{|c|}{ Equation (2) } & \multicolumn{4}{|c|}{ Equation (1) } \\
\hline & $\Delta \mathrm{GB} 2 \mathrm{Y}$ & $\triangle \mathrm{SWAP30D}$ & $\Delta \mathrm{GPI}$ & $\Delta \mathrm{GB} 2 \mathrm{Y}$ & $\triangle \mathrm{SWAP30D}$ & $\Delta$ GPI & $\Delta \mathrm{GDP}$ \\
\hline \multirow{4}{*}{ Error Correction } & \multicolumn{7}{|c|}{ Speed of adjustment } \\
\hline & $-0.191 * * *$ & -0.000462 & $-0.153 * * *$ & $-0.226^{* * *}$ & 0.00753 & -0.0951 & $-0.244 * * *$ \\
\hline & $(0.0403)$ & $(0.0135)$ & $(0.0519)$ & $(0.0479)$ & $(0.0162)$ & $(0.0644)$ & $(0.0904)$ \\
\hline & \multicolumn{7}{|c|}{ Short-run relationship } \\
\hline \multirow[t]{2}{*}{$\Delta \mathrm{GB} 2 \mathrm{Y}(\mathrm{t}-1)$} & 0.120 & $0.102 * * *$ & $0.285 * *$ & 0.128 & $0.0941 * * *$ & $0.275 * *$ & -0.0158 \\
\hline & $(0.0860)$ & $(0.0287)$ & $(0.111)$ & $(0.0857)$ & $(0.0289)$ & $(0.115)$ & $(0.162)$ \\
\hline \multirow[t]{2}{*}{$\Delta \mathrm{GB} 2 \mathrm{Y}(\mathrm{t}-2)$} & -0.0197 & 0.0375 & -0.0576 & -0.0103 & 0.0369 & -0.0595 & 0.0341 \\
\hline & $(0.0889)$ & $(0.0297)$ & $(0.114)$ & $(0.0871)$ & $(0.0294)$ & $(0.117)$ & $(0.165)$ \\
\hline \multirow[t]{2}{*}{$\triangle \mathrm{SWAP30D}(\mathrm{t}-1)$} & $0.452 *$ & $0.376^{* * *}$ & 0.248 & $0.511 * *$ & $0.366 * * *$ & 0.252 & 0.191 \\
\hline & $(0.254)$ & $(0.0849)$ & $(0.327)$ & $(0.253)$ & $(0.0855)$ & $(0.341)$ & $(0.478)$ \\
\hline \multirow[t]{2}{*}{$\triangle \mathrm{SWAP30D}(\mathrm{t}-2)$} & $0.424^{*}$ & $0.332 * * *$ & 0.449 & $0.645^{* *}$ & $0.345^{* * *}$ & 0.377 & 0.248 \\
\hline & $(0.245)$ & $(0.0821)$ & $(0.316)$ & $(0.252)$ & $(0.0852)$ & $(0.339)$ & $(0.477)$ \\
\hline \multirow[t]{2}{*}{$\Delta \mathrm{GPI}(\mathrm{t}-1)$} & -0.0140 & 0.0186 & $0.706^{* * *}$ & -0.00699 & 0.0110 & $0.708 * * *$ & 0.131 \\
\hline & $(0.0678)$ & $(0.0227)$ & $(0.0873)$ & $(0.0674)$ & $(0.0228)$ & $(0.0907)$ & $(0.127)$ \\
\hline \multirow[t]{2}{*}{$\Delta \mathrm{GPI}(\mathrm{t}-2)$} & $0.140 * *$ & 0.0248 & -0.0567 & $0.165^{* *}$ & 0.0237 & -0.0770 & -0.0926 \\
\hline & $(0.0704)$ & $(0.0235)$ & $(0.0907)$ & $(0.0701)$ & $(0.0237)$ & $(0.0943)$ & $(0.132)$ \\
\hline \multirow[t]{2}{*}{$\Delta \mathrm{GDP}(\mathrm{t}-1)$} & & & & 0.0651 & 0.0237 & 0.0928 & 0.119 \\
\hline & & & & $(0.0438)$ & $(0.0148)$ & $(0.0588)$ & $(0.0827)$ \\
\hline \multirow[t]{2}{*}{$\Delta \mathrm{GDP}(\mathrm{t}-2)$} & & & & $0.102 * *$ & 0.0182 & 0.000118 & $0.229 * * *$ \\
\hline & & & & $(0.0445)$ & $(0.0150)$ & $(0.0599)$ & $(0.0841)$ \\
\hline \multirow[t]{2}{*}{ Constant } & -0.0139 & -0.00785 & 0.0174 & 0.0173 & -0.00589 & 0.0328 & -0.0290 \\
\hline & $(0.0501)$ & $(0.0167)$ & $(0.0645)$ & $(0.0493)$ & $(0.0167)$ & $(0.0663)$ & $(0.0932)$ \\
\hline Observations & 138 & 138 & 138 & 138 & 138 & 138 & 138 \\
\hline $\mathrm{P}>$ chi 2 & 0.0001 & 0.0000 & 0.0000 & 0.0000 & 0.0000 & 0.0000 & 0.0017 \\
\hline R-square & 0.1953 & 0.6945 & 0.5097 & 0.2406 & 0.706 & 0.4958 & 0.1814 \\
\hline
\end{tabular}

Notes: Standard errors in parentheses. ${ }^{* * *} \mathrm{p}<0.01,{ }^{* *} \mathrm{p}<0.05,{ }^{*} \mathrm{p}<0.1$.

When considering longer-term government bond yields, GPI is statistically significant, meaning that the longer-term inflation rate is an important factor in determining government bond yields. For example, columns 2 and 5 of table 9 show that the yield on GB10Y adjusted by a factor of 0.101 percentage points and 0.14 percentage points, respectively, to its long-run equilibrium. 
Table 9: Speed of Adjustment and Short-Run Relationship to VECM for Equation (3) and Equation (4)

\begin{tabular}{|c|c|c|c|c|c|c|c|}
\hline \multirow[b]{2}{*}{ VARIABLES } & \multicolumn{3}{|c|}{ Equation (4) } & \multicolumn{4}{|c|}{ Equation (3) } \\
\hline & $\Delta \mathrm{GB} 10 \mathrm{Y}$ & $\triangle$ SWAP30D & $\Delta \mathrm{GPI}$ & $\Delta \mathrm{GB} 10 \mathrm{Y}$ & $\triangle \mathrm{SWAP30D}$ & $\Delta \mathrm{GPI}$ & $\Delta \mathrm{GDP}$ \\
\hline & \multicolumn{7}{|c|}{ Speed of adjustment } \\
\hline \multirow[t]{3}{*}{ Error Correction } & $-0.101 * * *$ & -0.0112 & $-0.0910 * * *$ & $-0.137 * * *$ & -0.0109 & $-0.0716^{*}$ & $-0.165 * * *$ \\
\hline & $(0.0265)$ & $(0.00728)$ & $(0.0264)$ & $(0.0357)$ & $(0.00991)$ & $(0.0373)$ & $(0.0533)$ \\
\hline & \multicolumn{7}{|c|}{ Short-run relationship } \\
\hline \multirow[t]{2}{*}{$\Delta \mathrm{GB} 10 \mathrm{Y}(\mathrm{t}-1)$} & 0.00185 & $0.0560 * *$ & $0.242 * * *$ & 0.0351 & $0.0566^{* *}$ & $0.248 * * *$ & -0.0714 \\
\hline & $(0.0837)$ & $(0.0230)$ & $(0.0833)$ & $(0.0831)$ & $(0.0231)$ & $(0.0868)$ & $(0.124)$ \\
\hline \multirow[t]{2}{*}{$\Delta \mathrm{GB} 10 \mathrm{Y}(\mathrm{t}-2)$} & $-0.156^{*}$ & 0.00696 & $-0.184 * *$ & $-0.146^{*}$ & 0.0101 & $-0.181 * *$ & -0.109 \\
\hline & $(0.0868)$ & $(0.0239)$ & $(0.0864)$ & $(0.0857)$ & $(0.0238)$ & $(0.0896)$ & $(0.128)$ \\
\hline \multirow[t]{2}{*}{$\triangle \mathrm{SWAP} 30 \mathrm{D}(\mathrm{t}-1)$} & 0.284 & $0.458 * * *$ & 0.328 & 0.272 & $0.455 * * *$ & 0.387 & 0.0459 \\
\hline & $(0.301)$ & $(0.0826)$ & $(0.299)$ & $(0.297)$ & $(0.0825)$ & $(0.311)$ & $(0.443)$ \\
\hline \multirow[t]{2}{*}{$\triangle \mathrm{SWAP} 30 \mathrm{D}(\mathrm{t}-2)$} & 0.419 & $0.339 * * *$ & 0.260 & $0.640 * *$ & $0.372 * * *$ & 0.229 & 0.154 \\
\hline & $(0.300)$ & $(0.0823)$ & $(0.298)$ & $(0.305)$ & $(0.0847)$ & $(0.319)$ & $(0.456)$ \\
\hline \multirow[t]{2}{*}{$\Delta \mathrm{GPI}(\mathrm{t}-1)$} & -0.0297 & 0.0272 & $0.723 * * *$ & -0.0250 & 0.0220 & $0.736^{* * *}$ & 0.155 \\
\hline & $(0.0850)$ & $(0.0234)$ & $(0.0846)$ & $(0.0844)$ & $(0.0234)$ & $(0.0882)$ & $(0.126)$ \\
\hline \multirow[t]{2}{*}{$\Delta \mathrm{GPI}(\mathrm{t}-2)$} & 0.0710 & 0.0296 & -0.0608 & 0.101 & 0.0321 & -0.0765 & -0.106 \\
\hline & $(0.0881)$ & $(0.0242)$ & $(0.0877)$ & $(0.0881)$ & $(0.0244)$ & $(0.0921)$ & $(0.131)$ \\
\hline \multirow[t]{2}{*}{$\Delta \mathrm{GDP}(\mathrm{t}-1)$} & & & & -0.0165 & 0.0228 & 0.0746 & 0.104 \\
\hline & & & & $(0.0548)$ & $(0.0152)$ & $(0.0573)$ & $(0.0818)$ \\
\hline \multirow[t]{2}{*}{$\Delta \mathrm{GDP}(\mathrm{t}-2)$} & & & & $0.143 * * *$ & 0.0227 & 0.00883 & $0.213^{* * *}$ \\
\hline & & & & $(0.0552)$ & $(0.0153)$ & $(0.0577)$ & $(0.0824)$ \\
\hline \multirow[t]{2}{*}{ Constant } & -0.00478 & -0.00977 & 0.00651 & 0.0268 & -0.00471 & 0.0286 & -0.0344 \\
\hline & $(0.0624)$ & $(0.0171)$ & $(0.0621)$ & $(0.0613)$ & $(0.0170)$ & $(0.0641)$ & $(0.0915)$ \\
\hline Observations & 138 & 138 & 138 & 138 & 138 & 138 & 138 \\
\hline $\mathrm{P}>$ chi 2 & 0.0042 & 0.0000 & 0.0000 & 0.0007 & 0.0000 & 0.0000 & 0.0003 \\
\hline R-square & 0.1481 & 0.6809 & 0.5473 & 0.1931 & 0.1931 & 0.5273 & 0.2073 \\
\hline
\end{tabular}

Notes: Standard errors in parentheses. ${ }^{* * *} \mathrm{p}<0.01,{ }^{* *} \mathrm{p}<0.05,{ }^{*} \mathrm{p}<0.1$.

Table 9 shows the short-run relationship between variables based on equation (3) and equation (4). From column 2, the second lag of GB10Y is statistically significant. This implies that the current month's GB10Y is negatively affected by the two-month lagged GB10Y yield at 0.15 percentage points. The second lags of SWAP30D and GDP are statistically significant and positively influence the current month's GB10Y yield.

This empirical exercise shows that there is a positive relationship between the government bond yield and the short-term interest rate measured by SWAP30D. The relationship is statistically significant in the front end of the yield curve, but not so in the back end of the yield curve, 
though signs are always positive. The sign in the short-run to long-run deviation is negative, as expected. The findings provide some qualified support for Keynes's contention.

\section{Alternative Specification}

In this section, an alternative specification of determining the long-term interest rate is provided with a different set of independent variables. BGB yields (2-year and 10-year) are modeled as a function of the following independent variables: SELIC rate, CPI, and industrial production (IP). Unit root tests of these series are undertaken. ${ }^{10}$ The variables are nonstationary in their levels but are stationary in their first differences. Thus, GB2Y, GB10Y, SELIC, CPI, and IP are integrated with order I(1).

Then the optimal lag length is checked. The rank of cointegration between the variables is determined following the same procedure as discussed in the previous section (lag length and cointegration test). Table 10 presents the optimal lag length based on different selection criteria. The optimal lag length is chosen based on the AIC. From table 10, it is evident that for both GB2Y and GB10Y, AIC suggests four lags as the optimal lag length, though it varies for HQIC and SBIC when the industrial production index is included in the model. For example, part A is where the model includes variables GB2Y, SELIC, and CPI. In this scenario, the AIC suggests a lag of four, while HQIC and SBIC suggest lags of two and one, respectively. If IP is included in the model, AIC still suggests four as the optimal number of lags, whereas HQIC and SBIC both suggest one as an optimal lag. In this paper, the AIC is used to choose the optimal lag length.

$$
\Delta Z_{t}=\alpha \beta^{\prime} Z_{t-1}+\sum_{i=1}^{p-1} \Gamma_{i} \Delta Z_{t-i}+v+\delta t+\epsilon_{t}
$$

where

\footnotetext{
${ }^{10}$ The results are provided in the appendix tables A1 and A2.
} 


$$
\begin{gathered}
Z=[G B 2 Y, \quad \text { SELIC }, C P I, I P]^{\prime} \ldots \\
Z=[G B 2 Y, S E L I C, C P I]^{\prime} \ldots \ldots \\
Z=[G B 10 Y, \quad \text { SELIC }, C P I, I P]^{\prime} \\
Z=[G B 10 Y, \quad \text { SELIC }, C P I]^{\prime} \ldots
\end{gathered}
$$

\begin{tabular}{|c|c|c|c|c|c|c|}
\hline Lag & LL & LR & FPE & AIC & $\mathrm{HQIC}$ & SBIC \\
\hline \multicolumn{7}{|c|}{ Part A: Variables: GB2Y, SELIC, CPI } \\
\hline 0 & -771.558 & & 16.343 & 11.307 & 11.333 & 11.371 \\
\hline 1 & -182.443 & $1,178.230$ & 0.003 & 2.839 & 2.943 & $3.094 *$ \\
\hline 2 & -164.671 & 35.544 & 0.003 & 2.711 & $2.892 *$ & 3.158 \\
\hline 3 & -159.116 & 11.110 & 0.003 & 2.761 & 3.021 & 3.400 \\
\hline 4 & -137.066 & $44.1^{*}$ & $0.003 *$ & $2.57^{*}$ & 2.908 & 3.402 \\
\hline \multicolumn{7}{|c|}{ Part B: Variables: GB2Y, SELIC, CPI, IP } \\
\hline 0 & $-1,195.212$ & & 471.182 & 17.507 & 17.541 & 17.592 \\
\hline 1 & -508.732 & $1,372.960$ & 0.026 & 7.719 & $7.892 *$ & $8.145^{*}$ \\
\hline 2 & -486.809 & 43.848 & 0.024 & 7.632 & 7.944 & 8.400 \\
\hline 3 & -476.003 & 21.610 & 0.026 & 7.708 & 8.158 & 8.816 \\
\hline 4 & -453.268 & $45.47^{*}$ & $0.024 *$ & $7.61 *$ & 8.199 & 9.059 \\
\hline \multicolumn{7}{|c|}{ Part C: Variables: GB10Y, SELIC, CPI } \\
\hline Lag & LL & LR & FPE & AIC & HQIC & SBIC \\
\hline 0 & -765.273 & & 14.910 & 11.216 & 11.242 & 11.280 \\
\hline 1 & -233.993 & $1,062.560$ & 0.007 & 3.591 & 3.695 & 3.847 \\
\hline 2 & -207.187 & 53.611 & 0.006 & 3.331 & 3.513 & $3.779 *$ \\
\hline 3 & -194.893 & 24.588 & 0.005 & 3.283 & 3.543 & 3.923 \\
\hline 4 & -173.801 & $42.185^{*}$ & $0.004 *$ & $3.107 *$ & $3.444^{*}$ & 3.938 \\
\hline \multicolumn{7}{|c|}{ Part D: Variables: GB10Y, SELIC, CPI, IP } \\
\hline Lag & LL & LR & FPE & AIC & HQIC & SBIC \\
\hline 0 & $-1,197.624$ & & 488.063 & 17.542 & 17.577 & 17.627 \\
\hline 1 & -553.060 & $1,289.127$ & 0.051 & 8.366 & 8.539 & 8.792 \\
\hline 2 & -528.242 & 49.637 & 0.044 & 8.237 & $8.549^{*}$ & $9.004 *$ \\
\hline 3 & -510.177 & 36.130 & 0.043 & 8.207 & 8.657 & 9.315 \\
\hline 4 & -485.268 & $49.819^{*}$ & $0.038^{*}$ & $8.077^{*}$ & 8.666 & 9.526 \\
\hline
\end{tabular}

Table 10: Lag Length Selection for Alternative Specification

Notes: * indicates the optimal lag length suggested by each criterion

Table 11 shows the rank test based on Johansen (1995) with restricted trend. Other specifications, as suggested by Johansen (1995), are tested. The results are similar for all these specifications even though the results are not provided here. For example, in table 11, part A, it is evident that the GB2Y, SELIC, CPI, and IP variables have one cointegration equation as 
indicated by the asterisk in the trace test. In part B, where IP is dropped from the estimation, the trace statistic suggests that there is no cointegration relationship, i.e., $r=0$. Similar results are evident for GB10Y, SELIC, CPI, and IP variables. Thus, for the VECM analysis, IP is always included in the model. ${ }^{11}$

Table 11: Rank Test for the Cointegration Equation

\begin{tabular}{|c|c|c|c|c|c|}
\hline Maximum rank & Parms & LL & Eigenvalue & Trace statistic & $5 \%$ Critical value \\
\hline \multicolumn{6}{|c|}{ Part A: Variables: GB2Y, SELIC, CPI, IP } \\
\hline 0 & 52 & -481.666 & & 64.115 & 62.990 \\
\hline 1 & 60 & -466.374 & 0.200 & $33.531 *$ & 42.440 \\
\hline 2 & 66 & -458.242 & 0.112 & 17.268 & 25.320 \\
\hline 3 & 70 & -453.538 & 0.066 & 7.860 & 12.250 \\
\hline 4 & 72 & -449.608 & 0.056 & & \\
\hline Maximum rank & Parms & LL & Eigenvalue & Max statistic & $5 \%$ Critical value \\
\hline 0 & 52 & -481.666 & & 30.583 & 31.460 \\
\hline 1 & 60 & -466.374 & 0.200 & 16.264 & 25.540 \\
\hline 2 & 66 & -458.242 & 0.112 & 9.408 & 18.960 \\
\hline 3 & 70 & -453.538 & 0.066 & 7.860 & 12.520 \\
\hline 4 & 72 & -449.608 & 0.056 & & \\
\hline \multicolumn{6}{|c|}{ Part B: Variables: GB2Y, SELIC, CPI } \\
\hline Maximum rank & Parms & LL & Eigenvalue & Trace statistic & $5 \%$ Critical value \\
\hline 0 & 30 & -154.087 & & $38.996^{*}$ & 42.440 \\
\hline 1 & 36 & -143.381 & 0.145 & 17.583 & 25.320 \\
\hline 2 & 40 & -138.871 & 0.064 & 8.564 & 12.250 \\
\hline 3 & 42 & -134.589 & 0.061 & & \\
\hline Maximum rank & Parms & LL & Eigenvalue & Max statistic & $5 \%$ Critical value \\
\hline 0 & 30 & -154.087 & & 21.413 & 25.540 \\
\hline 1 & 36 & -143.381 & 0.145 & 9.019 & 18.960 \\
\hline 2 & 40 & -138.871 & 0.064 & 8.564 & 12.520 \\
\hline 3 & 42 & -134.589 & 0.061 & & \\
\hline \multicolumn{6}{|c|}{ Part C: Variables: GB10Y, SELIC, CPI, IP } \\
\hline Maximum rank & Parms & LL & Eigenvalue & Trace statistic & 5\% Critical value \\
\hline 0 & 36 & -544.954 & & 68.651 & 62.990 \\
\hline 1 & 44 & -522.977 & 0.273 & $24.697 *$ & 42.440 \\
\hline 2 & 50 & -517.091 & 0.082 & 12.925 & 25.320 \\
\hline 3 & 54 & -513.663 & 0.048 & 6.069 & 12.250 \\
\hline 4 & 56 & -510.629 & 0.043 & & \\
\hline Maximum rank & Parms & LL & Eigenvalue & Max statistic & $5 \%$ Critical value \\
\hline 0 & 36 & -544.954 & & 43.954 & 31.460 \\
\hline 1 & 44 & -522.977 & 0.273 & 11.772 & 25.540 \\
\hline 2 & 50 & -517.091 & 0.082 & 6.856 & 18.960 \\
\hline 3 & 54 & -513.663 & 0.048 & 6.069 & 12.520 \\
\hline 4 & 56 & -510.629 & 0.043 & & \\
\hline
\end{tabular}

\footnotetext{
${ }^{11}$ Results based on the other specification suggested by Johansen (1995) were also checked. For all of these other
} specifications, results are similar. 


\begin{tabular}{rrrrrr}
\hline \multicolumn{2}{l}{ Part D: Variables: GB10Y, SELIC, CPI } & & & & \\
\hline Maximum rank & Parms & LL & Eigenvalue & Trace statistic & 5\% Critical value \\
\hline 0 & 21 & -211.881 & & $34.832 *$ & 42.440 \\
1 & 27 & -201.160 & 0.144 & 13.389 & 25.320 \\
2 & 31 & -197.399 & 0.053 & 5.867 & 12.250 \\
3 & 33 & -194.466 & 0.042 & & \\
\hline Maximum rank & Parms & LL & Eigenvalue & Max statistic & 5\% Critical value \\
\hline 0 & 21 & -211.881 & & 21.442 & 25.540 \\
1 & 27 & -201.160 & 0.144 & 7.522 & 18.960 \\
2 & 31 & -197.399 & 0.053 & 5.867 & 12.520 \\
3 & 33 & -194.466 & 0.042 & & \\
\hline
\end{tabular}

Table 12 presents the long-run relationship between the variables. The rank test confirms that there is only one cointegrating relation. Each column represents a long-run relationship between the variables. For example, column 2 (based on equation [5]) shows that all the variables are statistically significant. This indicates that GB2Y has a long-term relationship with SELIC, CPI, and IP. For example, for a 1 percent increase in the SELIC rate, GB2Y increases by 0.90 percentage points in the long run. With GB10Y (based on equation [7]) as a dependent variable along with the same independent variables, all the variables are statistically significant except for the trend term. It implies that a 1 percent increase in the SELIC rate increases the GB10Y by 0.70 percentage points in the long run.

Table 12: Long-Run Relationship under Alternative Specification

\begin{tabular}{lrr}
\hline Variables & Equation $(5)$ & Equation (7) \\
\hline GB2Y & 1 & --- \\
GB10Y & --- & 1 \\
SELIC & $-0.893 * * *$ & $-0.705 * * *$ \\
& $(0.119)$ & $(0.185)$ \\
CPI & $0.748 * * *$ & $1.237 * * *$ \\
& $(0.207)$ & $(0.322)$ \\
IP & $0.183 * * *$ & $0.299 * * *$ \\
& $(0.045)$ & $(0.070)$ \\
Trend & $0.011 * *$ & 0.012 \\
& $(0.005)$ & $(0.008)$ \\
\hline
\end{tabular}

Notes: Standard errors in parentheses. ${ }^{* * *} \mathrm{p}<0.01,{ }^{* *} \mathrm{p}<0.05,{ }^{*} \mathrm{p}<0.1$.

Table 13 shows the speed of adjustment coefficients and the short-run relationship between variables. The estimated models have statistically significant coefficients. For example, column 2 reports the estimation based on equation (5) with GB2Y as a dependent variable, where long-run equilibrium from a short-run disequilibrium is achieved at a rate of 0.137 percentage points in 
each month for GB2Y. Similarly, for GB10Y (based on equation [7]) the speed of convergence from a short-run disequilibrium to the long-run equilibrium is 0.138 percentage points per month in column 2 in table 14.

Table 13: Speed of Adjustment and Short-Run Relationship to VECM for Equation (5)

\begin{tabular}{|c|c|c|c|c|}
\hline VARIABLES & $\Delta \mathrm{GB} 2 \mathrm{Y}$ & $\triangle \mathrm{SELIC}$ & $\Delta \mathrm{CPI}$ & $\Delta \mathrm{IP}$ \\
\hline & \multicolumn{4}{|c|}{ Speed of adjustment } \\
\hline \multirow[t]{3}{*}{ Error Correction } & $-0.137 * *$ & $0.0846 * * *$ & -0.0395 & -0.431 \\
\hline & $(0.0550)$ & $(0.0245)$ & $(0.0266)$ & $(0.273)$ \\
\hline & \multicolumn{4}{|c|}{ Short-run relationships } \\
\hline \multirow[t]{2}{*}{$\Delta \mathrm{GB} 2 \mathrm{Y}(\mathrm{t}-1)$} & 0.152 & $0.0901 * *$ & $0.115^{* *}$ & 0.757 \\
\hline & $(0.0930)$ & $(0.0415)$ & $(0.0450)$ & $(0.462)$ \\
\hline \multirow[t]{2}{*}{$\Delta \mathrm{GB} 2 \mathrm{Y}(\mathrm{t}-2)$} & -0.0114 & 0.0254 & 0.0192 & 0.182 \\
\hline & $(0.0948)$ & $(0.0423)$ & $(0.0459)$ & $(0.471)$ \\
\hline \multirow[t]{2}{*}{$\Delta \mathrm{GB} 2 \mathrm{Y}(\mathrm{t}-3)$} & $0.178^{*}$ & 0.0570 & -0.0180 & 0.551 \\
\hline & $(0.0945)$ & $(0.0421)$ & $(0.0457)$ & $(0.470)$ \\
\hline \multirow[t]{2}{*}{$\Delta \operatorname{SELIC}(\mathrm{t}-1)$} & 0.150 & $-0.155 * *$ & 0.0794 & -0.0522 \\
\hline & $(0.175)$ & $(0.0781)$ & $(0.0848)$ & $(0.871)$ \\
\hline \multirow[t]{2}{*}{$\Delta \operatorname{SELIC}(\mathrm{t}-2)$} & $0.316^{*}$ & 0.0651 & 0.0832 & 0.295 \\
\hline & $(0.173)$ & $(0.0772)$ & $(0.0838)$ & $(0.860)$ \\
\hline \multirow[t]{2}{*}{$\Delta \operatorname{SELIC}(\mathrm{t}-3)$} & 0.0546 & $0.342 * * *$ & 0.0568 & -0.604 \\
\hline & $(0.171)$ & $(0.0764)$ & $(0.0829)$ & $(0.852)$ \\
\hline \multirow[t]{2}{*}{$\Delta \mathrm{CPI}(\mathrm{t}-1)$} & $0.421 * *$ & 0.0347 & $0.495 * * *$ & -0.0401 \\
\hline & $(0.190)$ & $(0.0847)$ & $(0.0919)$ & $(0.944)$ \\
\hline \multirow[t]{2}{*}{$\Delta \mathrm{CPI}(\mathrm{t}-2)$} & 0.0437 & 0.00587 & -0.0421 & -0.124 \\
\hline & $(0.209)$ & $(0.0929)$ & $(0.101)$ & (1.036) \\
\hline \multirow[t]{2}{*}{$\Delta \mathrm{CPI}(\mathrm{t}-3)$} & 0.237 & 0.0257 & 0.142 & -0.179 \\
\hline & $(0.191)$ & $(0.0853)$ & $(0.0925)$ & $(0.950)$ \\
\hline \multirow[t]{2}{*}{$\Delta \mathrm{IP}(\mathrm{t}-1)$} & 0.0277 & -0.00352 & -0.00861 & -0.0345 \\
\hline & $(0.0196)$ & $(0.00874)$ & $(0.00949)$ & $(0.0974)$ \\
\hline \multirow[t]{2}{*}{$\Delta \mathrm{IP}(\mathrm{t}-2)$} & $0.0579 * * *$ & -0.00533 & 0.00863 & 0.108 \\
\hline & $(0.0194)$ & $(0.00864)$ & $(0.00938)$ & $(0.0963)$ \\
\hline \multirow[t]{2}{*}{$\Delta \mathrm{IP}(\mathrm{t}-3)$} & -0.00630 & 0.00491 & 0.0117 & 0.0576 \\
\hline & $(0.0194)$ & $(0.00866)$ & $(0.00940)$ & $(0.0965)$ \\
\hline \multirow[t]{2}{*}{ Constant } & 0.0118 & -0.0301 & 0.0132 & -0.0108 \\
\hline & $(0.0544)$ & $(0.0242)$ & $(0.0263)$ & $(0.270)$ \\
\hline Observations & 137 & 137 & 137 & 137 \\
\hline $\mathrm{P}>$ chi2 & 0.0198 & 0.0000 & 0.0000 & 0.5280 \\
\hline R-square & 0.1807 & 0.5969 & 0.3592 & 0.0962 \\
\hline
\end{tabular}

Notes: Standard errors in parentheses. ${ }^{* * *} \mathrm{p}<0.01,{ }^{* *} \mathrm{p}<0.05,{ }^{*} \mathrm{p}<0.1$. 
Table 13 shows the short-run relationships between variables. Based on the optimal lag length selection, the optimal lag length is three and there is one cointegration equation. For example, in column 2, there are three lags for each individual variable. For the variable changes of GB2Y, the third lag of GB2Y is statistically significant, which implies that GB2Y is impacted by its own values in the prior three months. GB2Y is impacted by SELIC with a two-period lag, CPI with a one-period lag, and IP with two-period lag. In column 3, most of the variables are statistically insignificant when the trend term is suppressed in the regression.

Table 14: Speed of Adjustment and Short-Run Relationship to VECM for Equation (7)

\begin{tabular}{|c|c|c|c|c|}
\hline VARIABLES & $\Delta \mathrm{GB} 10 \mathrm{Y}$ & $\triangle \mathrm{SELIC}$ & $\Delta \mathrm{CPI}$ & $\Delta \mathrm{IP}$ \\
\hline & \multicolumn{4}{|c|}{ Speed of Adjustment } \\
\hline \multirow[t]{3}{*}{ Error Correction } & $-0.138 * * *$ & $0.0338^{*}$ & $-0.0488 * * *$ & $-0.409 * *$ \\
\hline & $(0.0429)$ & $(0.0175)$ & $(0.0176)$ & $(0.181)$ \\
\hline & \multicolumn{4}{|c|}{ Short-run relationship } \\
\hline \multirow[t]{2}{*}{$\Delta \mathrm{GB} 10 \mathrm{Y}(\mathrm{t}-1)$} & 0.0509 & 0.0408 & 0.0452 & 0.127 \\
\hline & $(0.0885)$ & $(0.0361)$ & $(0.0363)$ & $(0.373)$ \\
\hline \multirow[t]{2}{*}{$\Delta \mathrm{GB} 10 \mathrm{Y}(\mathrm{t}-2)$} & $-0.154^{*}$ & -0.0412 & -0.0273 & -0.306 \\
\hline & $(0.0852)$ & $(0.0348)$ & $(0.0350)$ & $(0.359)$ \\
\hline \multirow[t]{2}{*}{$\Delta \mathrm{GB} 10 \mathrm{Y}(\mathrm{t}-3)$} & 0.0928 & 0.0408 & 0.0290 & 0.256 \\
\hline & $(0.0881)$ & $(0.0359)$ & $(0.0361)$ & $(0.371)$ \\
\hline \multirow[t]{2}{*}{$\Delta \operatorname{SELIC}(\mathrm{t}-1)$} & 0.237 & -0.0213 & $0.143 *$ & 0.404 \\
\hline & $(0.195)$ & $(0.0796)$ & $(0.0800)$ & $(0.822)$ \\
\hline \multirow[t]{2}{*}{$\Delta \operatorname{SELIC}(\mathrm{t}-2)$} & $0.434 * *$ & $0.149 *$ & 0.0847 & 0.408 \\
\hline & $(0.190)$ & $(0.0777)$ & $(0.0781)$ & $(0.803)$ \\
\hline \multirow[t]{2}{*}{$\Delta \operatorname{SELIC}(\mathrm{t}-3)$} & 0.0524 & $0.393 * * *$ & 0.0722 & -0.489 \\
\hline & $(0.193)$ & $(0.0789)$ & $(0.0794)$ & $(0.815)$ \\
\hline \multirow[t]{2}{*}{$\Delta \mathrm{CPI}(\mathrm{t}-1)$} & $0.459 * *$ & 0.111 & $0.531 * * *$ & 0.279 \\
\hline & $(0.220)$ & $(0.0899)$ & $(0.0904)$ & $(0.929)$ \\
\hline \multirow[t]{2}{*}{$\Delta \mathrm{CPI}(\mathrm{t}-2)$} & -0.0243 & 0.0748 & -0.0109 & 0.271 \\
\hline & $(0.243)$ & $(0.0993)$ & (0.0999) & (1.026) \\
\hline \multirow[t]{2}{*}{$\Delta \mathrm{CPI}(\mathrm{t}-3)$} & 0.316 & 0.0596 & 0.145 & -0.194 \\
\hline & $(0.223)$ & $(0.0912)$ & $(0.0917)$ & $(0.942)$ \\
\hline \multirow[t]{2}{*}{$\Delta \mathrm{IP}(\mathrm{t}-1)$} & $0.0442 *$ & 0.00443 & -0.00300 & -0.00304 \\
\hline & $(0.0228)$ & $(0.00933)$ & $(0.00938)$ & $(0.0963)$ \\
\hline \multirow[t]{2}{*}{$\Delta \mathrm{IP}(\mathrm{t}-2)$} & $0.0904 * * *$ & 0.00208 & 0.0128 & 0.145 \\
\hline & $(0.0224)$ & $(0.00916)$ & $(0.00921)$ & $(0.0946)$ \\
\hline \multirow[t]{2}{*}{$\Delta \mathrm{IP}(\mathrm{t}-3)$} & -0.0225 & 0.0124 & $0.0180 *$ & 0.115 \\
\hline & $(0.0230)$ & $(0.00938)$ & $(0.00943)$ & $(0.0969)$ \\
\hline \multirow[t]{2}{*}{ Constant } & 0.0281 & -0.0173 & 0.0148 & -0.0127 \\
\hline & $(0.0622)$ & $(0.0254)$ & $(0.0255)$ & $(0.262)$ \\
\hline Observations & 137 & 137 & 137 & 137 \\
\hline $\mathrm{P}>$ chi 2 & 0.0006 & 0.0000 & 0.0000 & 0.3535 \\
\hline $\mathrm{R}$-square & 0.2350 & 0.5391 & 0.3710 & 0.1119 \\
\hline
\end{tabular}

Notes: Standard errors in parentheses. ${ }^{* * *} \mathrm{p}<0.01,{ }^{* *} \mathrm{p}<0.05,{ }^{*} \mathrm{p}<0.1$. 
Table 14 shows the short-run relationship between variables. Based on the optimal lag length selection, the optimal lag length is three and there is one cointegration equation. For example, for the variable changes of GB10Y in column 2, the second lag of GB10Y is statistically significant, which implies that GB10Y is impacted by its own values for the prior two months. The GB10Y yield is impacted by SELIC with a two-period lag, CPI with a one-period lag, and IP with twoperiod lag. In column 3, the trend term in the regression is suppressed. Here the GB10Y yield is significantly affected by its own second lag.

The empirical exercises undertaken with the alternative specification here show that there is a positive relationship between government bond yields and the short-run interest rate, as measured by the SELIC rate. These findings hold for both factors in the front end and the back end of the yield curve. This supports Keynes' conjecture. The sign in the short-run to long-run deviation is negative, as expected.

These two different specifications of the models show that generally there is a positive relationship between the short-term interest rate and the long-term interest rate in Brazil. The findings are consistent with the Keynesian approach.

\section{CONCLUSION}

The empirical results obtained in this paper have implications for both macroeconomic policy and economic theory.

The results show that the Keynesian approach can be useful for modeling the dynamics of BGB yields. They reveal that a country's central bank can exert strong influence on long-term government bond yields and that the central bank's actions have a decisive influence on the Treasury yield curve. The results generally support Keynes's (1930, 352-353) contentions that: (1) "the long-term rate of interest will respond to the wishes of a Currency Authority which will be exerting its direct influence ... mainly on the short-term rate;" and (2) "the influence of the 
short-term rate of interest on the long-term rate is much greater than anyone ... would have expected."

The BCB's policy rate has a marked effect on BGBs' nominal yields. A higher (lower) shortterm interest rate is associated with a higher (lower) government bond yield. The BCB influences BGB yields through the policy rate on short-term interest rates, such as swap and SELIC rates.

The BCB's policy rate decision is affected by the statutory mandates, inflationary pressures, inflation expectations, and overall economic and financial conditions in Brazil. Nevertheless, the findings confirm that the BCB's monetary policy actions are a key driver of the long-term interest rate and the shape of the yield curve. Given its monetary sovereignty, the BCB has the operational ability and flexibility to effectively control BGBs' yields on government debt in local currency as necessary, provided that a floating exchange rate regime is maintained.

The findings from this paper can inform policy issues and discussions in Brazil related to government debt management, fiscal sustainability, fiscal policy, the central bank's ability to control long-term interest rates on government bonds, and the efficacy of monetary policy and the monetary transmission mechanism. The findings can also have policy implications for other emerging market countries, particularly in Latin America, who often deal with similar institutions, economic circumstances, and financial markets conditions as Brazil. Earlier studies of emerging markets with currency sovereignty, such as India (Akram and Das 2015, 2019a), align with the findings of this paper.

The results provide empirical information that can be useful to both long-standing debates and ongoing controversies in macroeconomic theory on a wide range of topics. These topics include the effects of monetary policy, quantitative easing, operational issues in central banking (Bindseil 2004; Fullwiler [2008] 2017), the fiscal theory of price (Bölükbaş 2018; Sims 2013), the efficient market hypothesis, government debt sustainability (Fullwiler 2016), fiscal austerity, fiscal policy, fiscal-monetary coordination (Tcherneva 2011), functional finance (Lerner 1943, 1947), modern money and chartalism (Wray 2012), and bond markets in emerging economics 
(Turner 2002). It is hoped that these findings will contribute to promoting sound and welfareenhancing public policies and further research on key macroeconomic issues. 


\section{REFERENCES}

Akram, T., and A. Das. 2014. "Understanding the Low Yields of the Long-Term Japanese Sovereign Debt." Journal of Economic Issues 48(2): 331-40.

- 2015. “A Keynesian Explanation of Indian Government Bond Yields.” Journal of Post Keynesian Economics 38(4): 565-87.

- 2017. "The Dynamics of Government Bond Yields in the Eurozone." Annals of Financial Economics 12(3): (September) 1750011-18.

- 2019a. "The Long-Run Determinants of Indian Government Bond Yields." Asian Development Review 36(1): (March) 168-205.

—. 2019b. "An Analysis of the Daily Changes in US Treasury Security Yields." Levy Economics Institute Working Paper No. 934 (August). Annandale-on-Hudson, NY: Levy Economics Institute of Bard College.

_. 2020. "Australian Government Bonds’ Nominal Yields: A Keynesian Perspective." Annals of Financial Economics 15(1): 2050003-1-2050003-20.

Akram, T., and H. Li. 2016. “The Empirics of Long-Term U.S. Interest Rates.” Levy Economics Institute Working Paper No. 863 (March). Annandale-on-Hudson, NY: Levy Economics Institute of Bard College.

—. 2017. “What Keeps Long-Term U.S. Interest Rates So Low?” Economic Modelling 60: (January) 380-390.

—. 2018. "The Dynamics of JGBs' Nominal Yields.” Levy Economics Institute Working Paper No. 906 (May). Annandale-on-Hudson, NY: Levy Economics Institute of Bard College.

- 2019. "The Impact of the Bank of Japan's Monetary Policy on Japanese Government Bonds' Low Nominal Yields.” Levy Economics Institute Working Paper No. 938 (October). Annandale-on-Hudson, NY: Levy Economics Institute of Bard College.

- 2020. "An Inquiry Concerning Long-Term U.S. Interest Rates Using Monthly Data." Applied Economics 52(24): 2594-2621.

Ardagna, S., F. Caselli, and T. Lane. 2007. "Fiscal Discipline and the Cost of Public Debt Service: Some Estimates for OECD Countries." The B.E. Journal of Macroeconomics 7(1): $1-33$.

Baldacci, E., and M. Kumar. 2010. "Fiscal Deficits, Public Debt, and Sovereign Bond Yields," IMF Working Paper No. 10/184. Washington DC: International Monetary Fund. 
Bindseil, U. 2004. Monetary Policy Implementation: Theory, Past, and Present. Oxford, UK, and New York: Oxford University Press.

Bölükbaş, M. 2018. "The Fiscal Theory of The Price Level: An Analysis for Fragile Countries." In İ. Şiriner and Z. Y. Kiliçkan (eds.), Institutions, Development \& Economic Growth. London, UK: IJOPEC Publications Limited.

Cardim de Carvalho, F. J. 2016a. "Looking into the Abyss? Brazil at the Mid-2010s." Journal of Post Keynesian Economics, 39(1): 93-114.

— 2016b. "The Narrow Path for Brazil." Policy Note 2016/2. Annandale-on-Hudson, NY: Levy Economics Institute of Bard College.

—. 2017. "Brazil Still in Troubled Waters." Public Policy Brief No. 2017/143. Annandaleon-Hudson, NY: Levy Economics Institute of Bard College.

Cebula, R. 2014. "An Empirical Investigation Into the Impact of US Federal Government Budget Deficits on the Real Interest Rate Yield on Intermediate-Term Treasury Issues, 19722012." Applied Economics 46(28): 3483-93.

Das, U. S., M. Papaioannou, G. Pedras, F. Ahmed, and J. Surti. 2010. "Managing Public Debt and Its Financial Stability Implications." IMF Working Paper 10/280. Washington, DC: International Monetary Fund.

Davidson, P. 2015. Post Keynesian Theory and Policy: A Realistic Analysis of the Market Oriented Capitalist Economy. Cheltenham, UK, and Northampton, MA: Edward Elgar.

Dickey, D. A., and W. A. Fuller. 1979. "Distribution of the Estimators for Autoregressive Time Series with a Unit Root." Journal of the American Statistical Association 74(366): 42731.

—. 1981. "Likelihood Ratio Statistics for Autoregressive Time Series With a Unit Root." Econometrica 49(4): 1057-72.

Fullwiler, S. T. 2016. "The Debt Ratio and Sustainable Macroeconomic Policy.” World Economic Review 7: 12-42.

—_. (2008) 2017. "Modern Central Bank Operations: The General Principles." In L.-P. Rochon and S. Rossi (eds.), Advances in Endogenous Money Analysis. Northampton, MA: Edward Elgar.

Goodheart, C. A. E. 1998. "Two Concepts of Money: Implications for the Analysis of Optimal Currency Areas." European Journal of Political Economy 14(3): 407-32.

Gruber, J. W., and S. B. Kamin. 2012. "Fiscal Positions and Government Bond Yields in OECD Countries," Journal of Money, Credit, and Banking 44(8): 1563-87. 
Horioka, C. Y., T. Nomoto, and A. Terada-Hagiwara. 2014. "Why Has Japan's Massive Government Debt Not Wreaked Havoc (Yet)?" The Japanese Political Economy 40(2): $3-23$.

Hoshi, T., and T. Ito. 2013. "Is the Sky the Limit? Can Japanese Government Bonds Continue to Defy Gravity?” Asian Economic Policy Review 8(2): 218-47.

— 2014. "Defying Gravity: Can Japanese Sovereign Debt Continue to Increase Without a Crisis?" Economic Policy 29(77): 5-44.

International Monetary Fund. 2019a. "2019 Article IV Consultation-Press Release; Staff Report; and Statement by the Executive Director for Brazil." IMF Country Report No. 19/242. Washington, DC: International Monetary Fund.

—. 2019b. "Brazil: Staff Report for the 2019 Article IV Consultation.” IMF Country Report No. 19/243. Washington, DC: International Monetary Fund.

Jaramillo, L., and A. Weber. 2013. "Bond Yields in Emerging Economies: It Matters What State You Are In.” Emerging Markets Review 17: 169-85.

Johansen, S. 1995. Likelihood-Based Inference in Cointegrated Vector Autoregressive Models. Oxford, UK: Oxford University Press.

Keynes, J. M. 1930. A Treatise on Money, Vol. II: The Applied Theory of Money. London: Macmillan.

—. (1936) 2007. The General Theory of Employment, Interest, and Money. New York: Palgrave Macmillan.

Knapp, G. F. (1926) 1973. The State Theory of Money. Clifton, NY: A. M. Kelley.

Kregel, J. 2009. "The Global Crisis and the Implications for Developing Countries and the BRICS: Is the 'B' Really Justified?” Brazilian Journal of Political Economy 29(4): 34156.

- 2011. "Was Keynes' Monetary Policy A Outrance in the Treatise, A Forerunner of ZIRP and QE? Did He Change His Mind in the General Theory?" Policy Note No. 2011/4. Annandale-on-Hudson, NY: Levy Economics Institute of Bard College.

Kurihara, Y. 2015. "Asset Price and Monetary Policy: The Japanese Case.” Journal of Applied Finance and Banking 5(4): 1-9.

Lavoie, M. 2014. Post-Keynesian Economics: New Foundations. Cheltenham, UK and Northampton, MA: Edward Elgar.

Lerner, A. P. 1943. "Functional Finance and the Federal Debt." Social Research 10(1): 38-51. 
. 1947. "Money as a Creature of the State." American Economic Review 37(2): 312-17.

Levrero, E. S., and M. Deleidi. 2019. "The Causal Relationship Between Short-and Long-Term Interest Rates: An Empirical Assessment of the United States.” MPRA Paper No. 93608. Munich: Munich University Library.

Macrobond. Various years. Macrobond subscription services. https://www.macrobond.com (accessed November 10, 2019).

Martinez, L. B., A. Tercenoa, and M. Teruelb. 2013. "Sovereign Bond Spreads Determinants in Latin American Countries: Before and During the XXI Financial Crisis." Emerging Markets Review 17: 60-75.

Malliaropulos, D., and P. Migiakis. 2018. "Quantitative Easing and Sovereign Bond Yields: A Global Perspective.” Bank of Greece Working Paper No. 253. Athens: Bank of Greece.

Mattos, O. B., F. Da Roz, F. O. Ultremare, and G. S. Mello. 2019. "Unconventional Monetary Policy and Negative Interest Rates: A Post-Keynesian Perspective on the Liquidity Trap and Euthanasia of the Rentier." Review of Keynesian Economics 7(2): 185-200.

Min, H. G., D. H. Lee, C. Nam, M. C. Park, and S. H. Nam. 2003. "Determinants of EmergingMarket Bond Spreads: Cross-Country Evidence.” Global Finance Journal 14(3): 271-86.

Nielsen, B. 2006. "Order Determination in General Vector Autoregressions." Institute of Mathematical Statistics, Lecture Notes- Monograph Series 52: 93-112. Nuffield College, University of Oxford. https://projecteuclid.org/euclid.lnms/1196285968

Patra M. D., S. Pattanaik, J. John and H. K. Behera. 2016. "Monetary Policy Transmission in India: Do Global Spillovers Matter?” RBI Occasional Papers 37 (1 \& 2). Mumbai: Reserve Bank of India.

Phillips, P. C. B., and P. Perron. 1988. "Testing for a Unit Root in Time Series Regression." Biometrika 75(2): 335-46.

Poghosyan, T. 2014. "Long-Run and Short-Run Determinants of Sovereign Bond Yields in Advanced Economies." Economic Systems 38(1): 100-14.

Reinhart, C. M., and K. S. Rogoff. 2009. This Time Is Different: Eight Centuries of Financial Folly. Princeton, NJ: Princeton University Press.

Riefler, W. W. 1930. Money Rates and Money Markets in the United States. New York and London: Harper \& Brothers.

Sau, L. 2018. "Coping with Deflation and the Liquidity Trap in the Eurozone: A Post Keynesian Approach." Journal of Post Keynesian Economics 41(2): 210-35. 
Simoski, S. 2019. "A Keynesian Exploration of the Determinants of Government Bond Yields for Brazil, Colombia, and Mexico." Master of Science thesis, Levy Institute Graduate Programs in Economic Theory and Policy. Annandale-on-Hudson, NY: Levy Economics Institute of Bard College. https://digitalcommons.bard.edu/levy_ms/16

Sims, C. A. 2013. "Paper Money.” American Economic Review 103(2): 563-84.

Tcherneva, P. R. 2011. "Bernanke's Paradox: Can He Reconcile His Position on the Federal Budget with His Recent Charge to Prevent Deflation?" Journal of Post Keynesian Economics 33(3): 411-34.

Tkačevs, O., and K. Vilerts. 2016. "The Impact of Sovereign Bond Yields on Fiscal Discipline.” Latvijas Banka Working Paper No. 5/2016. Riga, Latvia: Latvijas Banka.

—. 2019. "The Impact of Government Borrowing Costs on Fiscal Discipline." Kyklos 729(3): 446-71.

Turner, P. 2002. "Bond Markets in Emerging Economies: An Overview of Policy Issues." BIS Papers No. 11. Basel: Bank for International Settlements.

Wray, L. R. (1998) 2003. Understanding Modern Money: The Key to Full Employment and Price Stability. Paperback edition. Cheltenham, UK and Northampton, MA: Edward Elgar.

2012. Modern Money Theory: A Primer on Macroeconomics for Sovereign Monetary Systems. New York: Palgrave Macmillan. 


\section{APPENDIX}

Table A1: ADF Unit Roots Test Under Alternative Specification

\begin{tabular}{|c|c|c|c|c|c|c|}
\hline Variables & Type & Observations & $\mathrm{ADF}$ & CV 1 & CV 5 & Lag \\
\hline SELIC & Drift & 137 & -1.967 & -2.356 & -1.657 & 6 \\
\hline SELIC & Trend & 139 & -2.067 & -4.028 & -3.445 & 6 \\
\hline SELIC & $\begin{array}{l}\text { No-trend and } \\
\text { drift }\end{array}$ & 139 & -0.735 & -2.595 & -1.950 & 6 \\
\hline CPI & Drift & 142 & -2.011 & -2.353 & -1.656 & 1 \\
\hline $\mathrm{CPI}$ & Trend & 139 & -1.807 & -4.026 & -3.444 & 1 \\
\hline CPI & $\begin{array}{l}\text { No-trend and } \\
\text { drift }\end{array}$ & 142 & -0.567 & -2.594 & -1.950 & 1 \\
\hline IP & Drift & 139 & -2.504 & -2.353 & -1.656 & 1 \\
\hline IP & Trend & 142 & -2.613 & -4.026 & -3.444 & 1 \\
\hline IP & $\begin{array}{l}\text { No-trend and } \\
\text { drift }\end{array}$ & 142 & -2.510 & -2.594 & -1.950 & 1 \\
\hline$\triangle$ SELIC & Drift & 139 & -2.500 & -2.354 & -1.656 & 2 \\
\hline$\triangle$ SELIC & Trend & 139 & -2.510 & -4.027 & -3.445 & 2 \\
\hline$\triangle$ SELIC & $\begin{array}{l}\text { No-trend and } \\
\text { drift }\end{array}$ & 139 & -2.500 & -2.595 & -1.950 & 2 \\
\hline$\Delta \mathrm{CPI}$ & Drift & 139 & -3.233 & -2.355 & -1.657 & 5 \\
\hline$\Delta \mathrm{CPI}$ & Trend & 137 & -3.332 & -4.028 & -3.445 & 5 \\
\hline$\Delta \mathrm{CPI}$ & $\begin{array}{l}\text { No-trend and } \\
\text { drift }\end{array}$ & 139 & -3.251 & -2.595 & -1.950 & 5 \\
\hline$\Delta \mathrm{IP}$ & Drift & 139 & -5.000 & -2.354 & -1.656 & 3 \\
\hline$\Delta \mathrm{IP}$ & Trend & 139 & -4.980 & -4.027 & -3.445 & 3 \\
\hline$\Delta \mathrm{IP}$ & $\begin{array}{l}\text { No-trend and } \\
\text { drift }\end{array}$ & 139 & -5.015 & -2.595 & -1.950 & 3 \\
\hline
\end{tabular}

Notes: ADF statistic presents the calculated statistic for the variables following the ADF model with the optimal lag length. Lag length is selected based on AIC. CV1 and CV5 presents critical value for 1 percent and 5 percent levels of significance, respectively. 
Table A2: PP Unit Roots Test Under Alternative Specification

\begin{tabular}{llccccc}
\hline Variables & Type & Observations & PP stat & CV 1 & CV 5 & Lag \\
\hline SELIC & $\begin{array}{l}\text { No-trend and } \\
\text { drift }\end{array}$ & 143 & -1.100 & -2.594 & -1.95 & 4 \\
\hline SELIC & Trend & 143 & -1.413 & -4.026 & -3.444 & 4 \\
\hline CPI & $\begin{array}{l}\text { No-trend and } \\
\text { drift }\end{array}$ & 143 & -0.463 & -2.594 & -1.95 & 4 \\
\hline CPI & Trend & 143 & -1.603 & -4.026 & -3.444 & 4 \\
\hline IP & $\begin{array}{l}\text { No-trend and } \\
\text { drift }\end{array}$ & 143 & -2.897 & -2.594 & -1.95 & 4 \\
\hline IP & Trend & 143 & -3.031 & -4.026 & -3.444 & 4 \\
\hline$\Delta$ SELIC & $\begin{array}{l}\text { No-trend and } \\
\text { drift }\end{array}$ & 142 & -8.267 & -2.594 & -1.95 & 4 \\
\hline$\Delta$ SELIC & Trend & 142 & -8.323 & -4.026 & -3.444 & 4 \\
\hline$\Delta$ CPI & $\begin{array}{l}\text { No-trend and } \\
\text { drift }\end{array}$ & 142 & -6.707 & -2.594 & -1.95 & 4 \\
\hline$\Delta$ CPI & Trend & 142 & -6.810 & -4.026 & -3.444 & 4 \\
\hline$\Delta$ IP & $\begin{array}{l}\text { No-trend and } \\
\text { drift }\end{array}$ & 142 & -12.60 & -2.594 & -1.95 & 4 \\
\hline$\Delta$ IP & Trend & 142 & -12.52 & -4.026 & -3.444 & 4 \\
\hline
\end{tabular}

Notes: PP stat presents the calculated statistic for the variables following the PP model with the optimal lag length.

Lag length is selected based on AIC. CV1 and CV5 presents critical value for 1 percent and 5 percent levels of significance, respectively. 